\title{
Ethnoecology and ethnomedicinal use of fish among the Bakwele of southeastern Cameroon
}

Ethnoécologie et utilisation ethnomédicinale des poissons chez les Bakwele de Sud-Est Cameroun

Takanori Oishi

\section{OpenEdition}

\section{Journals}

Electronic version

URL: http://journals.openedition.org/ethnoecologie/2893

DOI: 10.4000/ethnoecologie.2893

ISSN: 2267-2419

\section{Publisher}

Laboratoire Eco-anthropologie et Ethnobiologie

\section{Electronic reference}

Takanori Oishi, «Ethnoecology and ethnomedicinal use of fish among the Bakwele of southeastern Cameroon », Revue d'ethnoécologie [Online], 10 | 2016, Online since 31 December 2016, connection on 19 April 2019. URL : http://journals.openedition.org/ethnoecologie/2893 ; DOI : 10.4000/ ethnoecologie.2893

This text was automatically generated on 19 April 2019

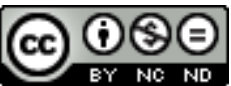

Revue d'ethnoécologie est mis à disposition selon les termes de la licence Creative Commons Attribution - Pas d'Utilisation Commerciale - Pas de Modification 4.0 International. 


\title{
Ethnoecology and ethnomedicinal use of fish among the Bakwele of southeastern Cameroon
}

Ethnoécologie et utilisation ethnomédicinale des poissons chez les Bakwele de

\author{
Sud-Est Cameroun
}

Takanori Oishi

\section{Introduction}

\section{Importance of ethnoichthyology in contemporary context of conservation}

1 Ethnoichthyology is a branch of ethnobiology, the studies of relationships between humans and fish, people's knowledge on fish and their utilization, and techniques of fish captures (Akimichi 1978, Ankei 1989, Paz \& Begossi 1996). It describes and analyses native lore and associated cultural values related to fish. In contrast to a number of researches on the other faunal taxa like mammals and birds, ethnoichthyological studies are still few. It is also the case for the study of fishing activities in tropical rainforest. Fishing in humid tropics with dense forest vegetation is smaller in scale than in savanna floodplain and so often overlooked and lower evaluated than hunting (Gragson 1992). However, since animal protein obtained from terrestrial mammals has become scarce, the potential of aquatic resources in Congo basin rainforest has drawn attention as an alternative resource to bushmeat in the context of conservation (Brashares et al. 2004, Rowcliffe et al. 2005, Brummett et al. 2010). In central DRC for instance, the contribution of fish to local people's diet increased each time that forest mammals were depleted during civil wars and related economic crises (Kimura et al. 2012). Whereas it is revealed that consumption of terrestrial fauna and aquatic fauna is related at a macro level (Brashares et al. 2004, Rowcliffe et al. 2005), risks of 'empty water' induced by overfishing also exists (Brummett 
et al. 2009). In this trend, we need more information on how local rainforest inhabitants of Congo basin perceive and utilize aquatic resources, especially fish.

\section{Diversified fishing techniques and their implications in a historical perspective}

Central African horticulturalists of the Congo Basin are known to implement diverse fishing techniques including bailing and stream poisoning, as well as the use of hooks and lines, several kinds of fish basket traps, and netting (Ankei 1989, Takeda 1990). Among diverse fishing method, the most common is certainly bailing (see also Comptour et al. this issue, Dounias et al. this issue, Gallois \& Duda this issue). Takeda (1990) pointed out that bailing fishing or puhanse plays a significant role in food ecology among the Ngandu of central Zaire as bailing fishing is highly reliable in harvest throughout the year. Hunting by Bantu speaking peoples is characterized by diverse trapping tactics, which enable to exploit mammals efficiently in limited areas of forest (Bahuchet 1993, Takeda 1990). Hunting and fishing are interrelated practices: For instance, borrowings of capture methods between fishing and hunting gears were reported in different parts of the Congo Basin, e.g. in DRC by Ankei (1989) in the Lualaba Basin, and by Hiroshi Masuda (personal communication) near Wamba. These authors speculate the application of hunting technologies - like trapping and spearing - to fishing.

Ethnolinguistic analysis of fishing specific vocabulary also indicates a contribution of ethnoichthyology to the better understanding of the history of the Congo Basin. In his tentative reconstitution of the history of Central Africa, Vansina (1990) suggests the existence of 'indigenous' pro-fisherfolks who were different from the ancestors of the current Pygmies. The livelihoods of these pro-fisherfolks were pending on inland capture fisheries in riverine environment, far before the penetration of the Bantu expansion (Vansina 1991). Pointing out the fact that different language groups over vast areas of the Congo Basin share common terms for a few fish species and fishing practices, Vansina speculated that the supposed pro-fisherfolks had been assimilated into various Bantu groups.

\section{Sociocultural dimension of small-scale fishing in multi-ethnic local communities}

4 A few previous studies have been exploring the social and cultural values pertaining to fish and fishing activities. For example, Japanese ecological anthropologists have drawn their attention on the social dimensions of fishing activities. Hanawa (2004) reports how the Bobanda and their neighboring Aka Pygmies changed their attitude towards each other during their shared seasonal settlement in fishing camps. Bobanda and Aka Pygmies ease tensions that were generated by imbalanced exchange between the labor force given by the Aka and the crops that they receive in return from the Bobanda. During the dry season, the two groups cooperate in dam fishing expeditions, which are occasions to restore peaceful relations between them (Hanawa 2004). Oishi (2010) observed similar social processes between the Bakwele and Baka Pygmies of southeastern Cameroon. Oishi argued the existence of a dual mode of social relationship construction among the Bakwele: they change their social mode of daily interactions when shifting from sedentary village to fishing camps, as a means to cope with social frustrations 
accumulated in the residential village. These frustrations are worked out and eventually evacuated during the seasonal stay in the fishing camps (Oishi 2010, 2014). In both cases, social boundaries constructed at the village tend to be weakened or ignored in fishing camps. Inai (2010) further explored this scope beyond the usual and stereotyped forager versus farmer dichotomy: He showed how immigrant commercial fishermen and local subsistence fishermen implement contrasting yet complementary fishing strategies. Instead of being a source of conflict, they result in a surprising cohabitation that is motivated by cumulative and reciprocal benefits between these two groups of fishers (Inai 2010).

5 On the basis of these previous studies, this paper will focus on the ethnoecology and ethnomedicine of fish among the Bakwele of southeastern Cameroon to explore the interactions between the ecological and sociocultural aspects of ethnoichthyology.

\section{The Bakwele and fishing activities}

\section{Outline of Bakwele ethnography}

6 The Bakwele speak a Bantu language, li-bekwil (Bakwele language) ${ }^{1}$, that Guthrie (1967-70) classified as A85b in Maka-Djem group. The Bakwele are organized in five regional groups of Mebeeza, Ebaa, Mekuoob, Essel, and Ebit scattered in northeastern Gabon, Northwestern and an enclave area of northeastern Congo Brazzaville, and southeastern Cameroon (Siroto 1969). Bakwele's population is estimated around 15,000 in total (Lewis et al. 2016) and around 1,500-2,000 in southeastern Cameroon 2. Documentation of Bakwele language and its local dialects are still poor (Cheucle 2008).

7 In southeastern Cameroon, most Bakwele are living along the Dja and Ngoko rivers. They distinguish themselves in two local groups: dja-ko (people of upper Dja) and dja-ce (people of lower Dja); dja-ko local group identity is shared among the people who had descended from the upper Dja and whose ethnic origins are hybrid of Bakwele Ebaa, Konabembe, and Djem; and dja-ce local identity is shared among the Bakwele Essel who had arrived from lower Dja and from the Congo side of Dja river. Many Bakewele can also speak lingala language as cultural and economic exchanges with Dja Congo side is frequent. The data used in this paper is mostly obtained from dja-ko. Reflecting this ethnic identity hybridization, local informants are used to multi-linguistic environments.

\section{Sedentarization process and Subsistence economies}

8 The Bakwele take strategy of multi-subsistence livelihoods (fishing, hunting, gathering, as well as subsistence farming and cash cropping) in similar to the other forest dwelling farmers like the Mvae and Ntumu of coastal Cameroon (Dounias et al. this issue) and the Bongando in the Central Congo Basin (Kimura 1992). The major part of cash income is obtained from cacao farming in southeastern Cameroon and in northwestern part of Republic of Congo (Oishi 2012). Whereas there are few fulltime fishermen among the Bakwele, fishing constitutes a considerable part of subsistence activities throughout the year, although with a prominent occurrence during dry seasons (Oishi 2010, 2014). The Bakwele use dugout canoes e-relle (me-relle) as well as walking to access to fishing sites. 
Bakwele subsistence economies are varying from region to region, but are overall based on shifting cultivation. Bakwele's cultivate plantain or cassava as a staple food crop, depending on the local hydrology and soil condition; plantain cultivation prevails in the area located in upland with clay soils whereas cassava cultivation dominates in the area with seasonal flooding and sandy soils (Mengho 1978). The Bakwele also cultivate cacao as a cash crop, which is their major source of cash income. They depend on the labor force provided by the Baka Pygmies (hunter-gatherers) who live adjacent for decades (Oishi 2012). Barter economy of food resources (agricultural staple foods versus forest products such as wild meat and honey) declined and wage labor became popular between the two ethnic groups under the penetration of market economy with increased influence of immigrant merchants on local cash economy (Oishi 2016).

10 The schedule of farming activities, especially those related to cacao production, determines the annual life cycle of the Bakwele. Households slash secondary forest vegetation during dry seasons and burn it just before the next rainy season. During the rainy season, people stay in their village, harvesting and processing cacao beans; hunting, fishing, and gathering are practiced nearby the village. During the major dry season, many people disperse into the forest - sometimes more than two months and generally far from their village - for long-term fishing and hunting expeditions that are called kpeti dik. Long-term fishing expeditions are often described by Bakwele as 'holidays' (Oishi 2010).

\section{Commercialization of fishing in southeastern Cameroon and Bakwele}

11 Industries such as mining and logging companies that extract tropical forest resources are highly demanding in animal protein supply to feed their employees. Fresh and smoked fish are consumed in quantity along with bushmeat (Figure 1). Such niche market is relatively short-term driven as an average logging phase in one place will last only up to ten years. Although I could not directly observe visits of fish buyers in the research site, there are truly trading networks between immigrant fishermen and fish vendors that are adjacent to cities and logging camps (Inai 2010). If the Bakwele capture fisheries intervene first and foremost as a source of animal protein for their own subsistence diet, they also to a lesser extent take part in this trade and constitute a secondary source of cash income.

12 Industrial fishing tools (fishing hooks, fishing nylon lines, fishing net made of cotton or nylon) are expensive for most of Bakwele. Nevertheless, fishing activities cannot become intensive without input from other sectors of their economy such as cash cropping and wage labor. In addition, the Bakwele take any member of their extensive families to their fishing camps and even bring livestock - chickens and goats - with them (Oishi 2010). Participants to fishing expeditions generally crave for fish, so most catches are consumed at fishing camps. Surplus catches, if any, are smoked and stored for weeks; they will be shared with absent family members, and might be sold if accumulated in great quantities (Oishi 2014). It is thus difficult to find any clear boundary between subsistence fishing and commercial fishing among the Bakwele. For many Bakwele, a fishing expedition is perceived as an opportunity to ensure a good nutritional health to their children by providing them with greater food intake - in quality, in quantify and in frequency - 
during the major dry season that is generally considered as critical in terms of food availability (Oishi 2014).

\section{Research area and natural environments}

Ndongo village, where I conducted intensive research, is located on the shore of the Dja river that delineates the international border between Cameroon and the Republic of Congo. The Bakwele population in the research site is estimated around 250 peoples, which is fewer than the nearly 300 Baka hunter-gatherers who live adjacently (Oishi 2010). Prior to their resettlement that was imposed by the French administration in the 1960s, the Bakwele were scattered in small number of households along the Dja river (Joiris 1998). The construction of the first motor road in the late 1970s by a Liberian logging company was a strong incentive for the Bakwele to leave their villages along the river and to resettle along the roadside.

\section{Water environment and flooding regime}

The Dja watershed is a branch of the broader Sangha system (Figure 1), which constitutes the extreme northwestern part of the Congo Basin (Brummett \& Teugels 2004). The Dja watershed is adjacent to that of the Sanaga, the Nyong, and the Ogooué, which belong to a distinct biogeographical water system called the Lower Guinea district. A scientific expedition conducted in the 1950s reported 160 fish species from the Dja (Vivien 1991). The water color of the Dja river is slightly brown and heavily turbid; the Bakwele term clear water as $\varepsilon$-jaasal and turbid water as bimis.

Figure 1: Location of the Dja watershed in the Congo Basin

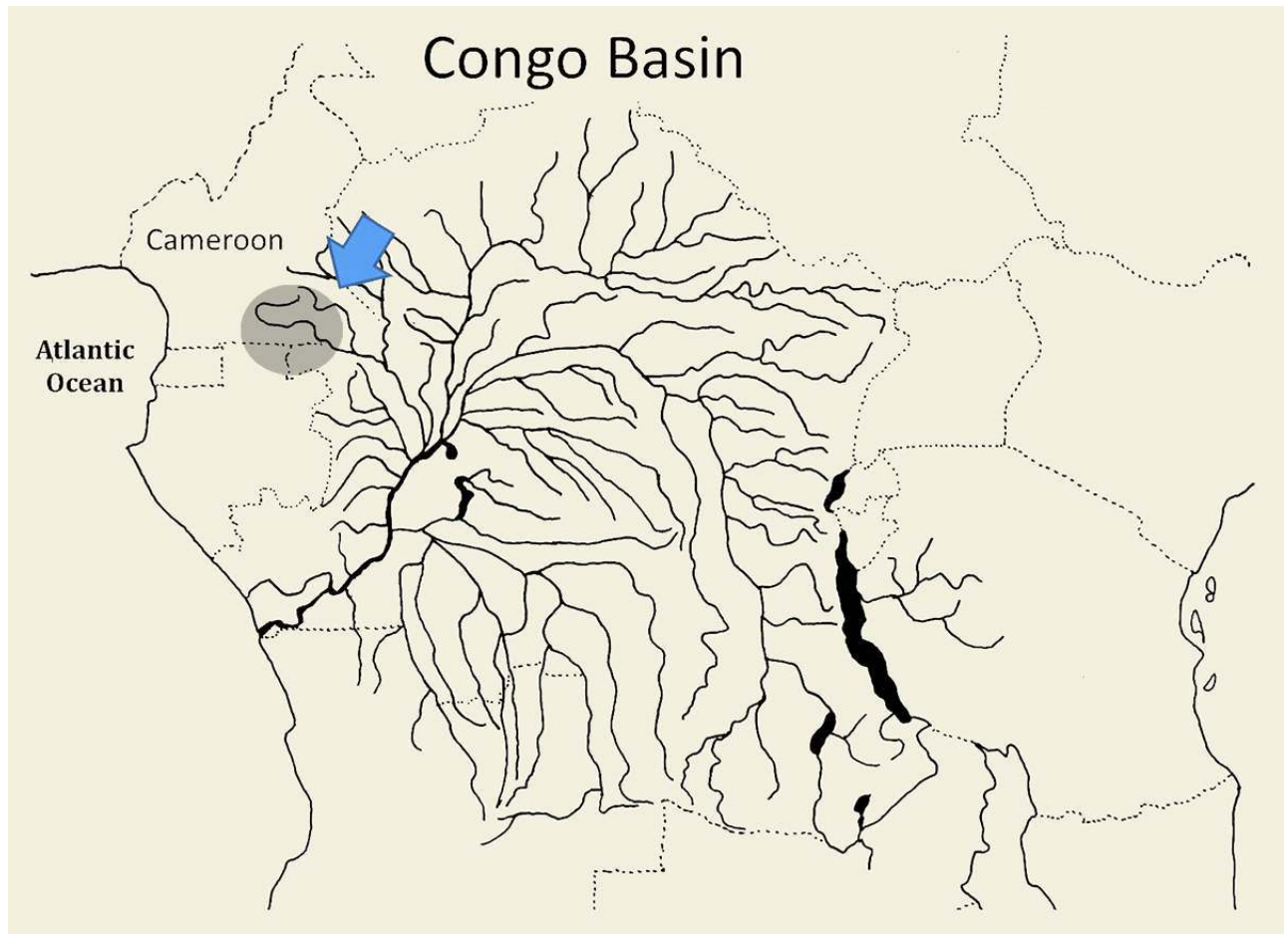


Annual mean temperature is around $25 \mathrm{C}^{\circ}$ and annual rainfall approximates $1,500 \mathrm{~mm}$ at the closest city of Moloundou. The overall climate type is four-seasons equatorial: There are two rainy seasons (April to June and September to November) and two dry seasons (July to August and December to March). The Bakwele recognize five seasons nbuu (minbuu) per year. In complement of the generic expressions mbú-be-bí (season of rain) and mbú-gués (season of shine) that respectively refer to a rainy and a dry season, specific seasonal episodes are termed such as panganí (minor rainy season), kuòl (minor dry season), ndua-kuòl (the period following minor dry season), and banga (beginning of major dry season). Seasonal fluctuations in rainfall create a dynamic cycle of water levels (Figure 2). This dynamic is expressed by the Bakwele as a succession of inundations biyou - in the middle of the major rainy season especially from October to the end of November - and droughts ngel - in the late major dry season from January to March. Even during a dry season, flash flooding bongo may occur after a sudden rain.

Figure 2: Monthly rainfall and water discharge at Dja river

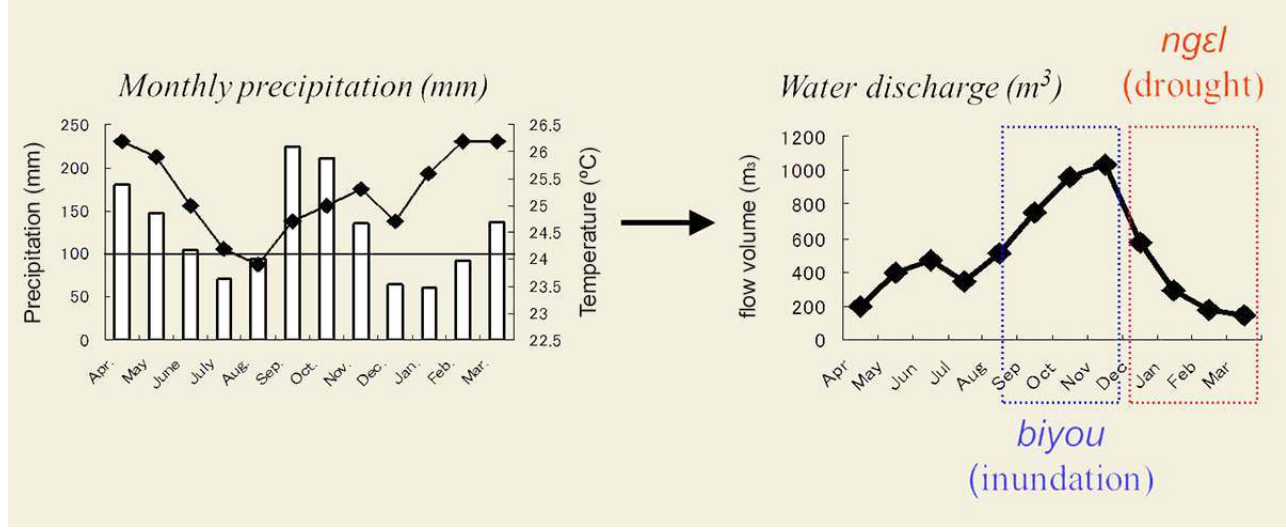

SOURCE: OISHI 2010

Rapid elevations of water flow during the rainy season can be a trigger to migration or reproduction of Cyprinids and Silurids fishes (Chapman 2001, Brummett \& Teugels 2004) and the season of most active fishing coincides with low water level periods. If lack of inundation continues for several years, it is recognized to result in decline of harvest due to these fish communities. Obvious seasonality in fishing and fish consumption records attests that fishing prevails in drier seasons (see Oishi \& Hagiwara 2015 for parallel trends in fish consumption in large cities). Previous study conducted near our study area (Lobéké National Park) also reported significant increase in fish catches in the later period of the major dry season (Makazi et al. 1998).

\section{Vegetation}

17 Forest vegetation plays a significant role in characterizing the various aquatic communities of African rainforest by contributing to maintain water quality with shading effect (Brummett \& Teugels 2004). A great diversity of vegetation types covers the research area: tropical evergreen forest, tropical semi-deciduous forest, riparian forest, swamps and wetlands; not forgetting human modified secondary forests at various stages of regeneration and resulting from human temporary residence for shifting cultivation, hunting, gathering, and fishing activities (Oishi \& Fongnzossie 2012), that Bakwele 
classify into ten landscapes: dik (generic term of 'forest'), mbal (wet savannah that the Bakwele do not recognize as 'forest'), zaab (wetland dominated by Raphia spp., the Bakwele do not recognize as 'forest'), हbit (agricultural fallow that the Bakwele recognize as 'forest'), nguur (forest regenerated after abandonment of villages or camps for fishing, hunting, and agriculture), saka (periodically flooded forest), meben (Gilbertiodendron dewevrei mono-dominant forest), biya, or bo-dik (generic term for 'primary forest', which refers to patches of forest that have not yet been used for slash-and-burn agriculture; bodik literally means 'big forest'), mekola ('primary forest' with thick understorey vegetation and fairly limited range of vision), and sclel $\boldsymbol{\varepsilon}$ ('primary forest' with sparse understorey vegetation that allows a long range of vision).

\section{Methodology}

\section{Participatory observation}

Field research has been carried out between 2003 and 2015, with more intensive observations during the major dry seasons of 2003, 2004 and 2007. I first made participatory observation on fishing activities on both long-term and distant fishing expeditions, and daily fishing activities close to the village. During participation, I collected data on fishing methods and techniques, on fishing engines, and on ichthyofauna by noting vernacular names and by taking specimens for further identification. Collected specimens were brought to the Ecology and Environmental Studies Laboratory in ASAFAS, Kyoto University, and were identified using identification keys by Boulenger (1909-16) and Poll \& Gosse (1995).

\section{Ethnoichthyological interview}

I made individual interviews on local knowledge about fish with seven adult male fishers - who were all born between the early 1920s and the late 1960s - from different Bakwele-Djako households. Four of them became key informants. All informants practiced fishing as a part-time activity of their livelihoods. In the procedure of semistructured interviews, I used 48 pictures of fish specimens that I took in the previous stage of my fieldwork. Pictures were shown in a random order and each informant was asked about fish habitat, size and diet, but also about fishing methods, taste and dietary value, medicinal use and any the other related knowledge. To better understand how people recognize and perceive fish, I also asked informants to draw fish on their own. French and Bakwele languages were spoken in the process of field survey, with the support of Bakwele research assistants to avoid misleading translations.

\section{Results and analysis}

\section{Fish names and folk classification}

The Bakwele group the fish under the term sù that refers to a classificatory category that clearly differs from 'humans', 'mammals', and 'birds' categories (Figure 3). Fish category is divided into 'fish with scale' (besu $\boldsymbol{\varepsilon}$ kpapa) and 'fish without scale' (besu $\boldsymbol{\varepsilon}$ djec). 
Figure 3: Position of fish in Bakwele ethnozoology

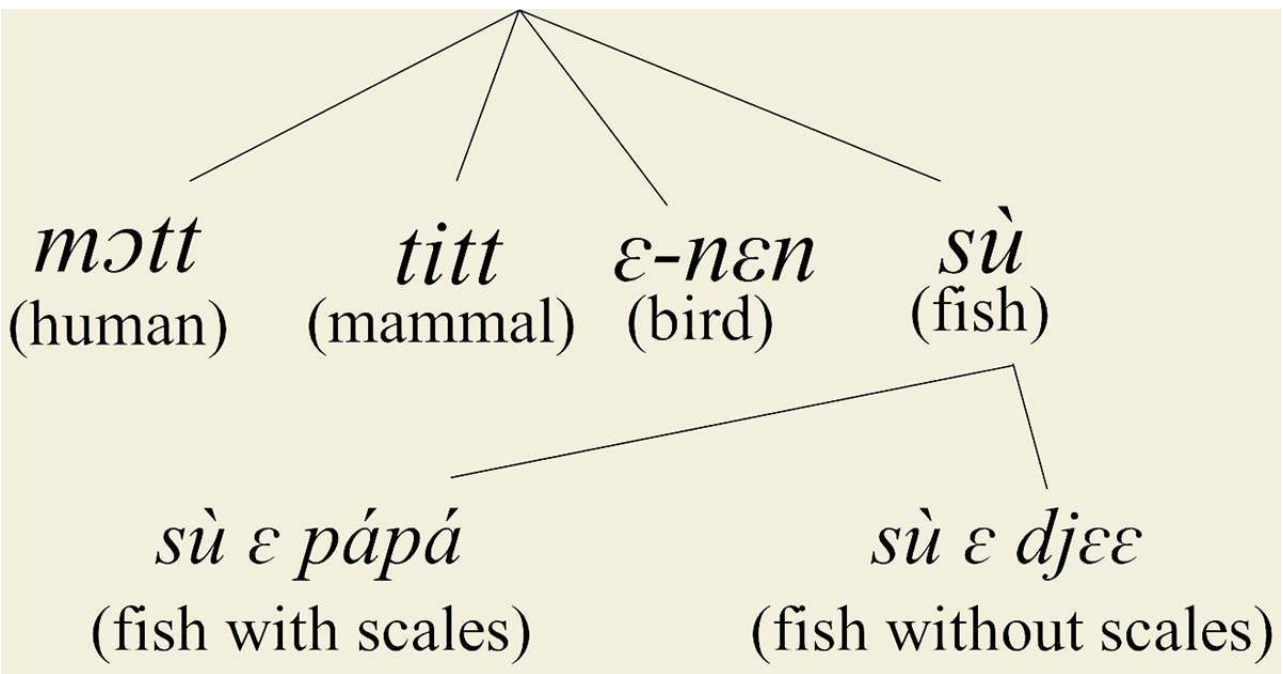

I could collect 97 species of fishes that belong to 22 families (Figure 4) and that the Bakwele recognize under 69 names $^{3}$. Scientific classification and Bakwele classification was compared at family level (Figure 4). For five ethnospecies, the Bakwele have distinctive Bakwele terms for naming successive life stages: Two terms for Hydrocynus vittatus, Labeo spp., Clarias gariepinus, and Heterobranchus longifilis; Three terms for Chrysichthys sp.

Figure 4: List of fish vernacular and scientific name. In case no specimen was collected, identification was attempted from sketches and photos

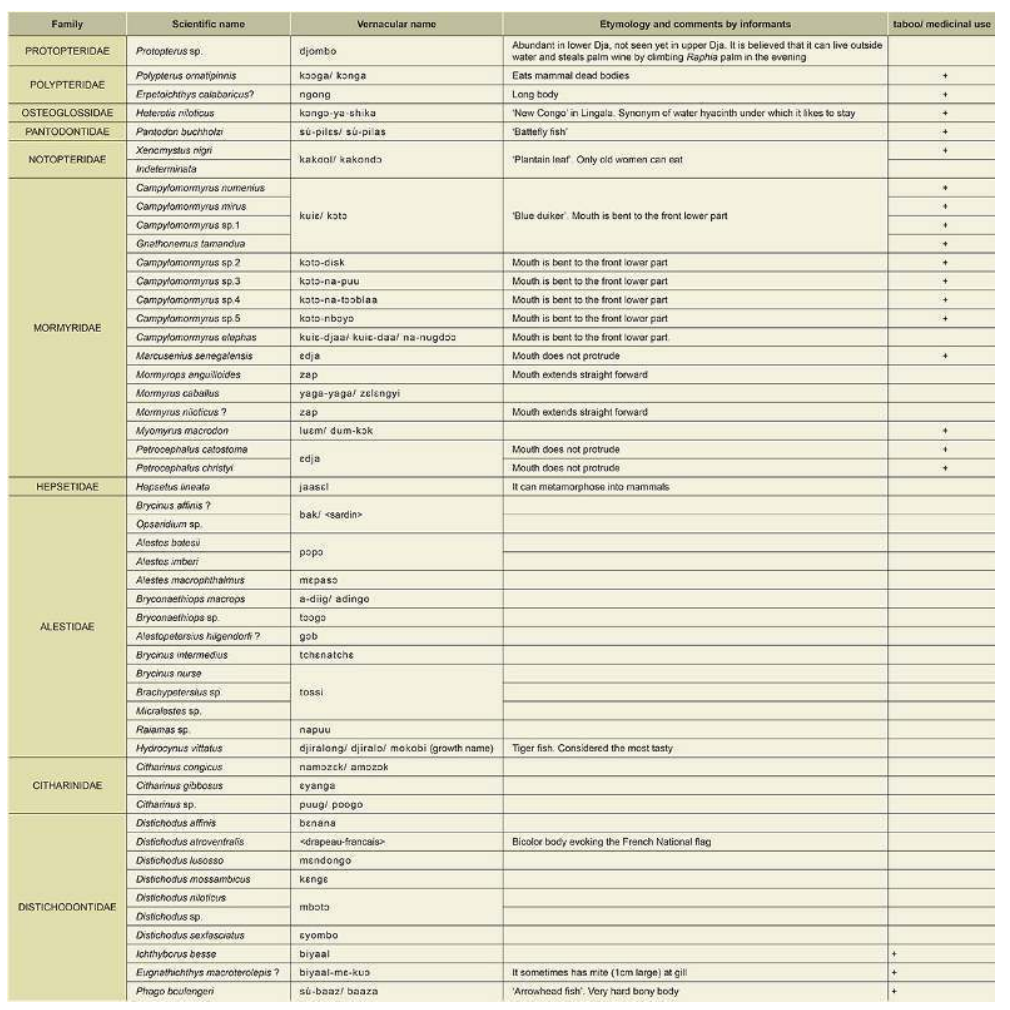




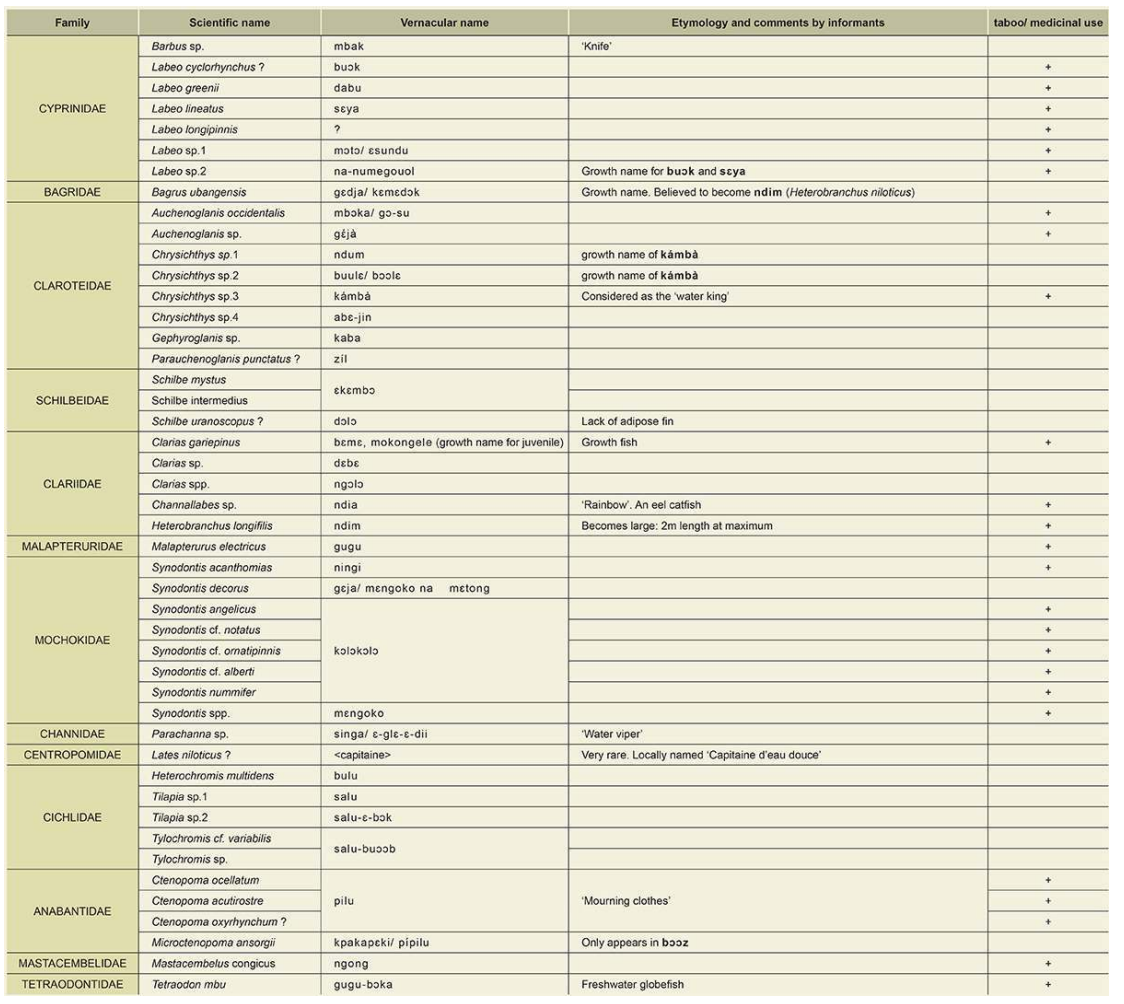

22 Scientific versus Bakwele classifications were compared at the family level (Figure 5). In eight families (Mormyridae, Alestidae, Mochokidae, Cyprinidae, Distichodontidae, Cichlidae, Schilbeidae, and Anabantidae), the vernacular lexicon is less precise than scientific names. Whereas I could not find clear Bakwele concept comparable to the 'ethno-family' evoked by Paz \& Begossi (1996) among the Brazilian coastal fishermen, the Bakwele have a few terms evoking ethno-species according to morphology, habitat, and use value for certain groups of fish. For instance, the Bakwele recognize three ethnosubfamilies of Mormyrids that are based on morphology and habitat criteria: koto, $\boldsymbol{\varepsilon}$ dja, and zap. They also have ethno-subfamilies for Alestids (popo and tossi), and Mochokids ( kolokolo and mengoko). 
Figure 5: Compared diversity of Bakwele fish names and scientifically recognized fish species for all the fish families inventoried in the study area

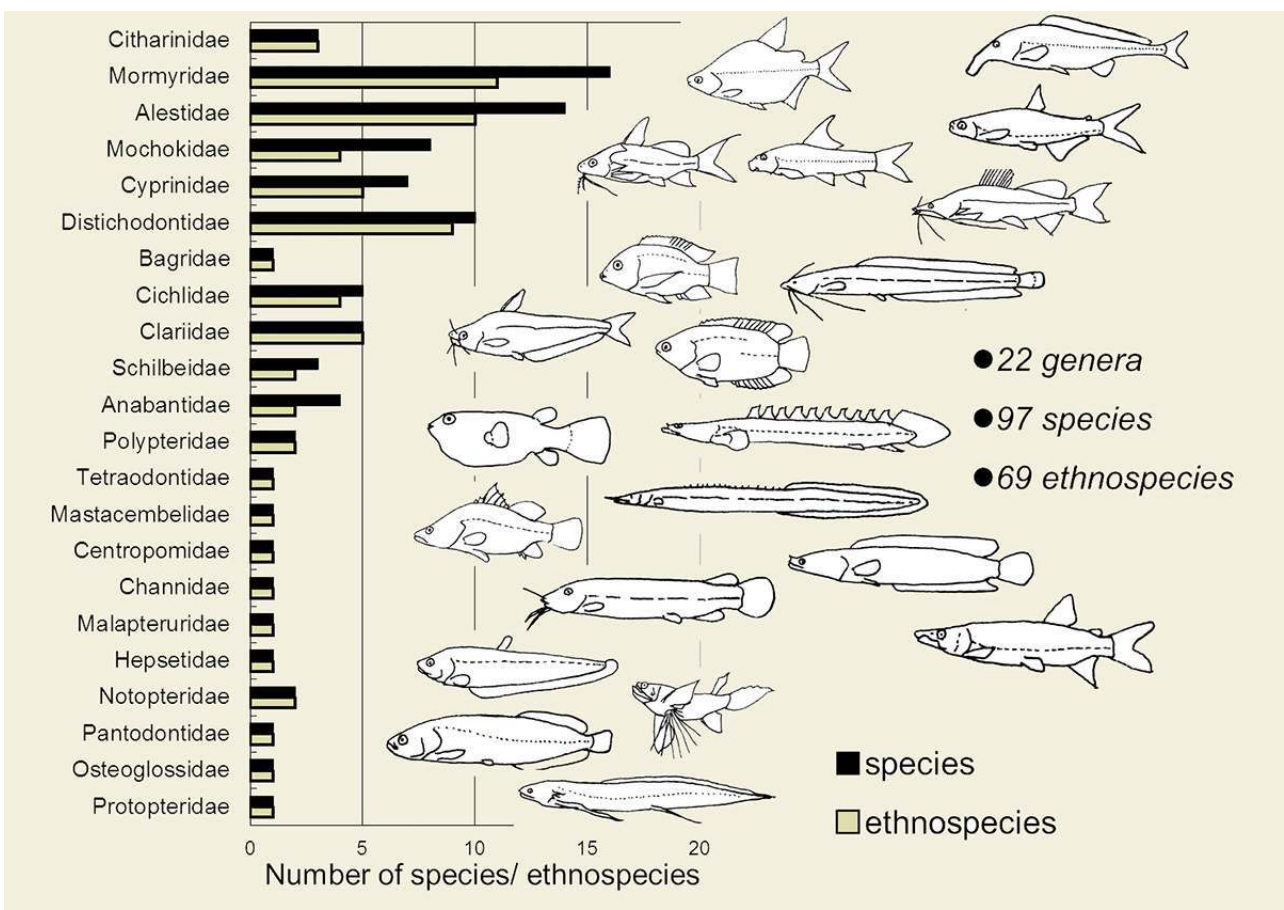

Drawings of fish by Bakwele fishers can give us information about how they look at and perceive fish (Figure 6). Siluriforms are generally depicted from directly above, when other species are mostly viewed laterally. Although my Bakwele informants recognized certain obvious physical characteristics, they interestingly tend to neglect them in their drawings, in favor of other less obvious parts of the depicted fish.

Figure 6: BUULU (Heterochromis miltidens)

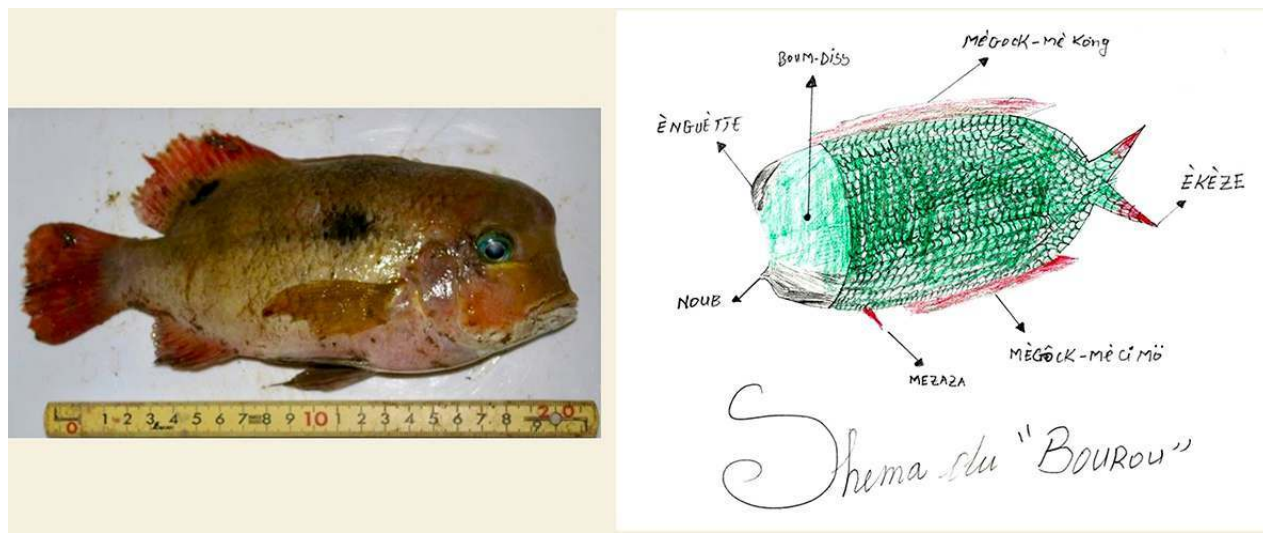

Picture: (c) T. Oishi and drawing by a Bakwele informant

Bakwele terms for some fish body parts: nuoub-sù (mouth), kpápá (scale), $\boldsymbol{\varepsilon}$-dok (gill),

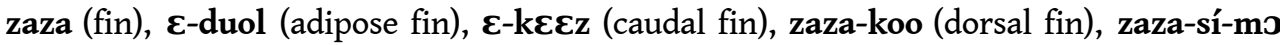
(pelvic fin), pe-tok (pectoral fin), siib (barbel), nja-sù (intestine)]

The use of aquatic resources by the Bakwele is not limited to fish. Various other aquatic fauna - amphibians, reptiles, crustaceans - are captured and tasted as food (Figure 7). The African dwarf crocodile Osteolaemus tetraspis is occasionally caught during bailing 
fishing. African water cobra Naja annulata sometimes enters fishing net. Frogs - Xenopus amieti and Silurana epytropicalis that are commonly termed nan'jama, but also Xenopus laevis - are major preys during dam fishing in the later half of the major dry seasons, when the catching of Clariid catfishes starts declining after repeated fishing exploitations. The African giant river prawns Macrobrachium spp. are not only heavily consumed by fisher households for their recognized nutritional values; they also represent a reliable source of income as they are sold 150 to 250 FCFA per deciliter in local markets (Makazi et al. 1998). Shrimp production is quite abundant in several villages close to the Lobéké National Park: Shrimps seem to favor specific streams for spawning in the middle of the major dry season (February). Crabs and aquatic snails also constitute appreciated snacks and side dishes.

Figure 7: Non-fish aquafauna (amphibians, reptiles, and crustaceans) captured by Bakwele fishers

\begin{tabular}{|c|c|c|}
\hline Class or Family & Scientific name & Vernacular name \\
\hline Pipidae & Xenopus amieti and Silurana epytropicalis & nan'Wama \\
\hline \multirow{3}{*}{ Palaemonidae } & Macrobranchium sp. 1 & mwas/ a-bunmyas \\
\hline & Macrobranchium sp. 2 & toogo \\
\hline & Shrimp (indeterminata) & ji $\varepsilon$ \\
\hline Characidae & Crab (indeterminata) & a-k£ko \\
\hline \multirow{4}{*}{ Crocodylidae } & (generic name of crocodile which grow large) & gęl \\
\hline & Mecistops cataphractus & koli \\
\hline & Crocodylus niloticus & mebuku \\
\hline & Osteolaemus tetraspis & nban \\
\hline GASTROPODA & Snail (indeterminata) & ngol-dii \\
\hline
\end{tabular}

\section{Knowledge on fish habitat}

The Bakwele classify waters into three generic categories: dii (river), zaab (marsh), and $\mathbf{b}$ OOz (waterpool). dii simply means watercourses as well as water itself. mo-dii (small river) corresponds to streams which pour into dii or bo-dii (big river). mo-dii often disappears when water recedes during the dry season and booz are formed after flooding during the major rainy season (Figure 8). Seasonal fluctuations of water level and watershed dynamics are rightfully expressed in Bakwele vocabulary. 
Figure 8: Inland water ecosystems as perceived by the Bakwele
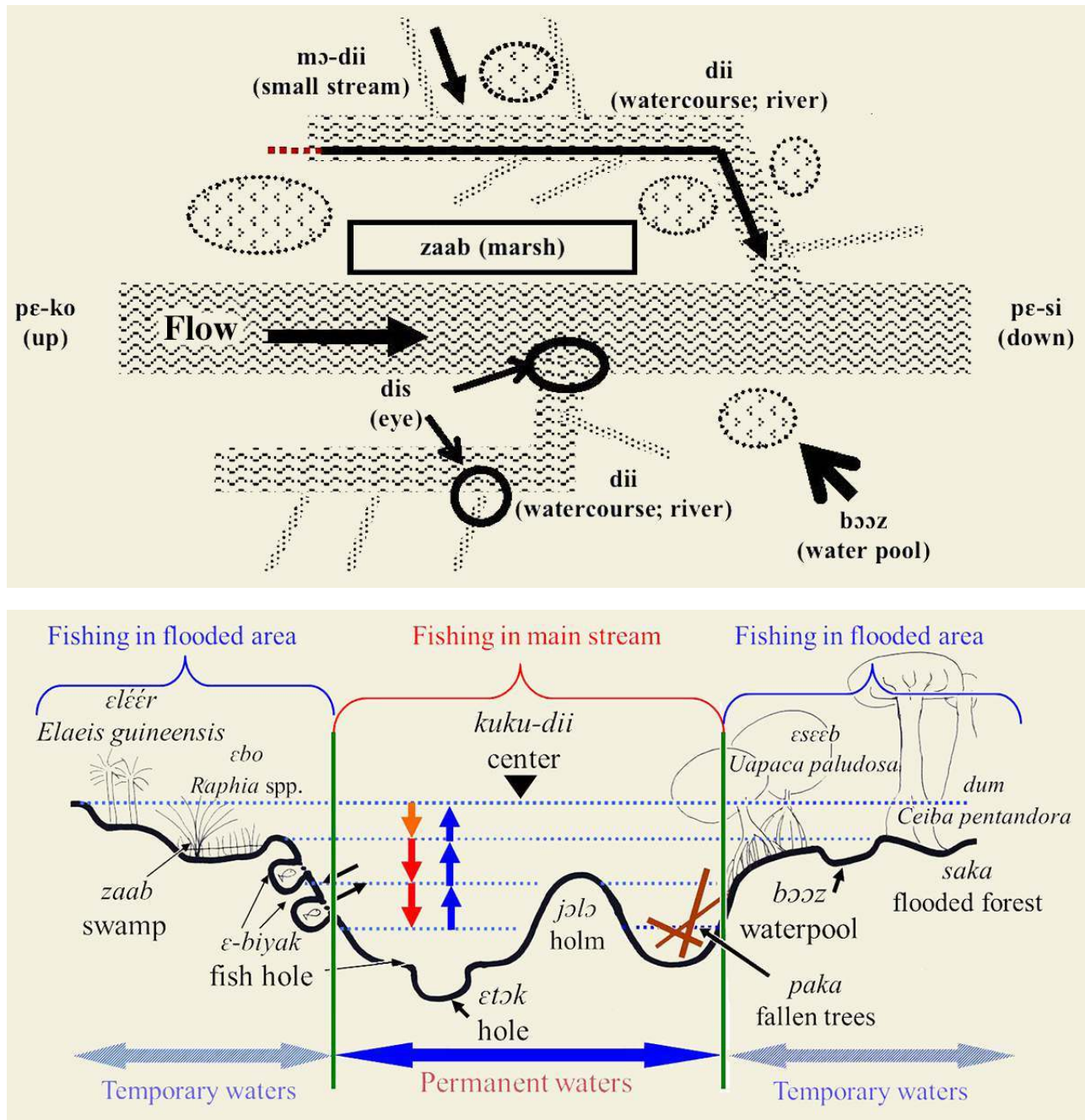

A: Bakwele perception of their water system (Source: Oishi 2006) - B: Aquatic water microhabitat as recognized by the Bakwele (Source: modified from Oishi 2010)

The following examples of folk terms occurring regularly during fisher interviews illustrate the richness of the Bakwele perception of their inland water environment:

$\boldsymbol{\varepsilon}$-biyák $\mathbf{k}^{4}$ is a hole or burrow on the bank of the upper part of a stream inside which fish, individually or in groups, takes refuge during the major dry season.

e-tok is a deep water site in the riverbed. It is viewed as a specific form of hole.

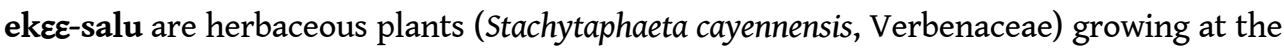
shore, which are used as 'indicators' of the likely presence of fish. (Figure 9)

sákà refers to the riparian forest that grows along the Dja river. Riverine edge of sákà is

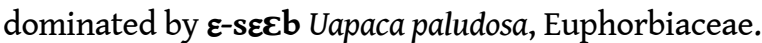

$\boldsymbol{\varepsilon}$-seहb Uapaca trees are carachterized by their stilt roots, known to form a privileged

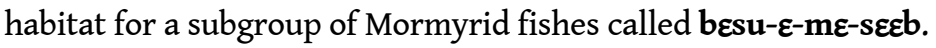

makúk is a narrow pool formed by fallen trees into the riverbed.

The dense vascularization of the Dja watershed results in an intricate presence of water inside every single part of the forest ecosystem. From the Bakwele perspective, inland 
waters and terra firma form in fact a unique and intermingled ecotone ${ }^{5}$. This interconnectedness between the two systems is well expressed by the Bakwele when they use the expression 'going to forest' as a mean to say that they go fishing.

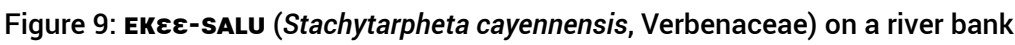

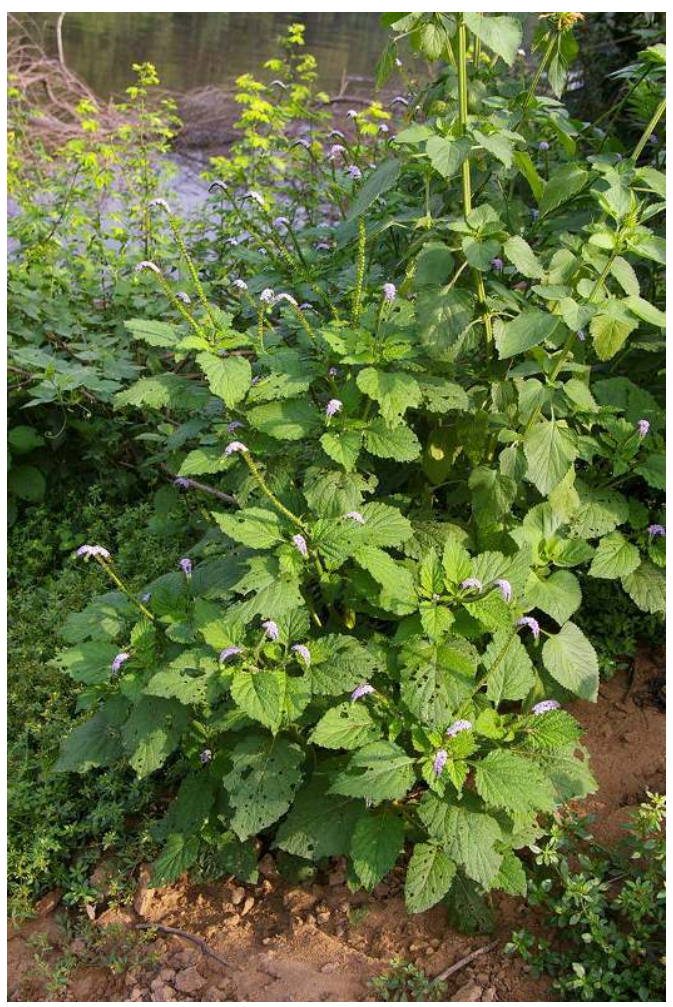

(C) T. OISHI

\section{Knowledge on fish diet and behavior}

Bakwele fishers have developed empirical knowledge on fish diet by looking at the content of the stomach content of the captured fish. Baits that are used for angling and longline fishing are chosen accordingly. Extensive knowledge has been also acquired through observation about fish group sizes, times of activities (diurnal versus nocturnal), habitat ranges, and specific behaviors. For instance, mendim is a term that expresses the fact to track ndim (Heterobranchus niloticus) further upriver, when inundation occurs during the rainy season.

\section{Fishing engines and techniques}

The Bakwele federate hunting and fishing activities under the unique term u-wa ('animal-killing'), specifying $\mathbf{u}$-wa-dii for fishing and $\mathbf{u}$-wa-chii[lu] for hunting. A fisher is called ngo-el-su ('killer of fish') while ngo-el-titt ('killer of mammals') refers to the hunter. ngo comes from the verb $\boldsymbol{\varepsilon}$-go ('to kill'). Those who excel in the art of fishing are

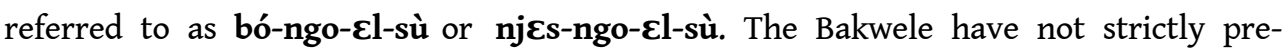
determined units of fishers or social structuration of fishing activitied. As far as gender differentiation is concerned, women, in collaboration with children, most exclusively 
perform three modalities of dam fishing (see Gallois \& Duda, this issue). By contrast, men are the sole users of spears, longlines and nets. Fishing with poison and fences as well as angling are practiced by both genders.

The use of dugout canoe e-relle facilitates access to a broad range of water habitats. Each Bakwele household residing near the Dja river possesses at least one dugout canoe. Dugout canoes are mostly made from 'ayous' (Triplochiton scleroxylon, Malvaceae), 'iroko' ( Milicia excelsa, Moraceae), 'sapelli' (Entandrophragma cylindricum, Meliaceae) and 'parasol tree' (Musanga cecropioides, Cecropiaceae). Hard wood species are preferred for a long lasting use, while the softness and lightness of the 'parasol tree' are more reliable for easy carrying and greater speed. The Bakwele control their dugout canoes using woody paddles wull and sticks $\mathbf{m} \varepsilon$ puku. mepuku is efficient to progress upstream against strong currents or to move in shallow waters during the dry seasons. Very few Bakwele can afford to invest into an expensive outbord engine wull-etelle ('paddle of the Whites'). Hand bailer toka made of 'Chinese bamboo' (mengoko, Bambusa vulgaris, Poaceae) or recycled poly tanks is used to scoop water out of the canoe.

\section{Fishing methods}

The Bakwele fishing methods are described below with special reference to their ecological knowledge.

\section{1 - Bail fishing}

Bail fishing elwok is very popular among women and children. It is sometimes referred to as 'women's fishing'. Elwok is a verb that literally means 'to bail'. Women use various containers for scoop the water out, such as metallic pots b' $\boldsymbol{\varepsilon}$ and woven baskets bwaa made from Marantaceae stems. elwok has two types according to the water environment: $\boldsymbol{\varepsilon}$ lwok p $\boldsymbol{\varepsilon}$ (mo)dii and $\boldsymbol{\varepsilon l w o k} \mathbf{p} \boldsymbol{\varepsilon}$ booz. The former is practiced flowing water, and the latter is practiced in temporary and still pools, which are formed during the dry season after that water has receded (Figure 8B). Bail fishing requires low water levels, so its practice concentrates during the dry seasons. Although men rarely take part in clwok, they may be accompanied by their wives and children when going to their remote fishing camps and they may occasionally participate. Bail fishing is a fishing activity commonly carried out by the Bakwele and the Baka women, who sometimes go fishing together.

1-1. elwok p $\varepsilon$ (mo)dii starts with the construction of a dam made of mud and twigs on stream in the forest (Figure 10). This dam is ephemeral and it will be broken by the water flow after 30 minutes to three hours. While the dam stops the water flow, water becomes scarce further downstream. Participants bail out the remaining water and directly catch fish, crabs, and shrimps. Participants explore hideouts in the banks, especially beneath tree roots. They will successively progress further downstream. 
Figure 10: Making temporary dam for $\varepsilon$ LWJK PE (MO)DII

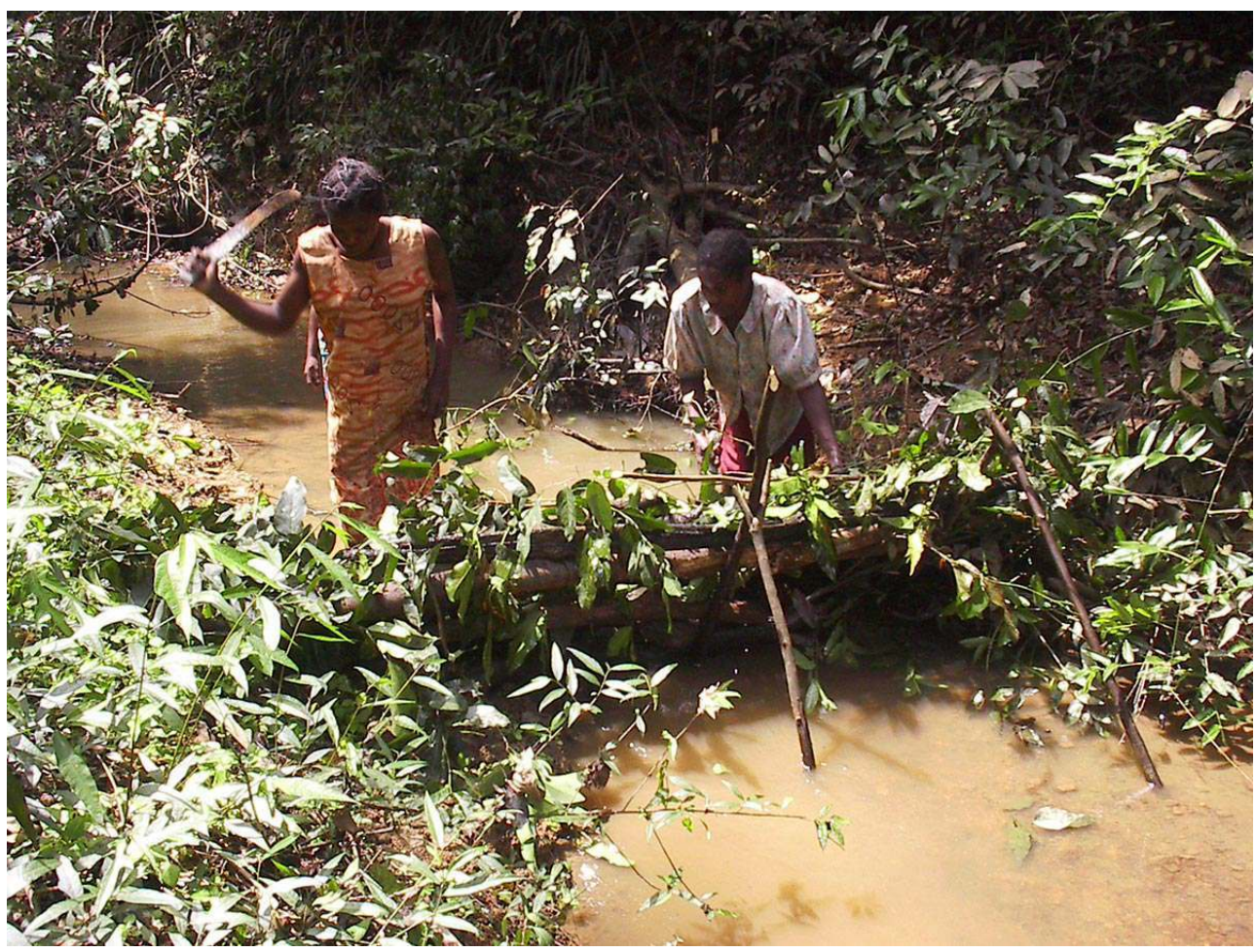

(C) T. OISHI

41 1-2. In عlwok pe booz, participants immediately start to bail water out if the waterpool b $\mathbf{O O z}$ is small or remaining water is scarce. If the pool is too large or contains too much water, participants will divide it by building dams. Participants dig deep into the fish holes $\varepsilon$-biyák to catch catfish and snakeheads (Figre 11). The distinct fish catches

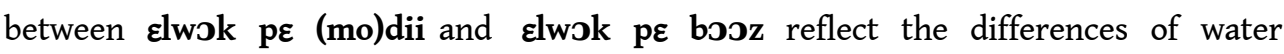
environment.

\section{Figure 11: Bail fishing}

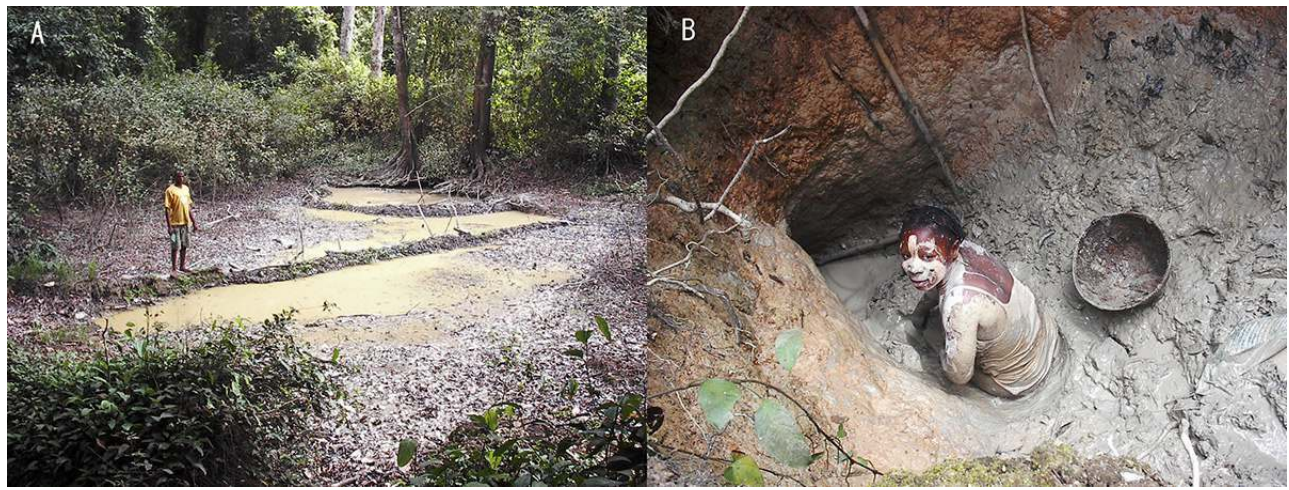

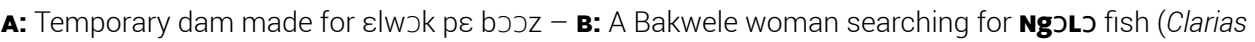
sp.) in a fish hole $\boldsymbol{\varepsilon}$-BIYÁk

(c) T. OISHI 


\section{2 - Poison fishing}

Poison fishing is called do (e-do) by the Bakwele. Though the Bakwele evoke the names of a dozen plant taxa to be used for poison fishing, I could observe the use of only three of them: mongonbo, asama, and momoma. In my observation case momoma (which means 'young woman who has strong power to enchant men') was used in combination with mongonbo. Bakwele and Baka similarly name these two plant species and the related fishing method. Poison fishing is principally practiced in groups, and it may sometimes be associated with other fishing practices, especially with bail fishing.

2-1. mongonbo (Millettia sanagana, Fabaceae) is a small vine tree that grows close to water courses. The Bakwele estimate that mongonbo is more poisonous than asama. mongonbo is practiced little affluents of the Dja river, far from the village. Poison preparation mobilizes more than 10 adults. As several households are involved in mongonbo the fishing expedition is generally planned in advance. The lead organizer of the poison fishing expedition is called pan'nama. Sexual intercourse is prohibited among participants before the day of poisoning. Participants should also not have meals before cutting mongonbo tree. When the first branch is cut, participants hold it altogether. Then pan'nama cut the branch mongonbo into pieces of 30-40 cm length and distribute them to all participants. Each of them hit their piece with hand-made wooden hummer to loosen the stem fibers that are rich in sap. When enough amount of poison is prepared, participants carry it further upstream. After reaching the appropriate site, the poison is mixed up with mud and soaked in the water. After a few minutes suffocating fish start to flow on the surface. The first catch shall be made by pan'nama. The capture may then continue for two to three hours (Figure 12).

Figure 12: Poison fishing using Mongonbo (Millettia sanagana, Fabaceae)

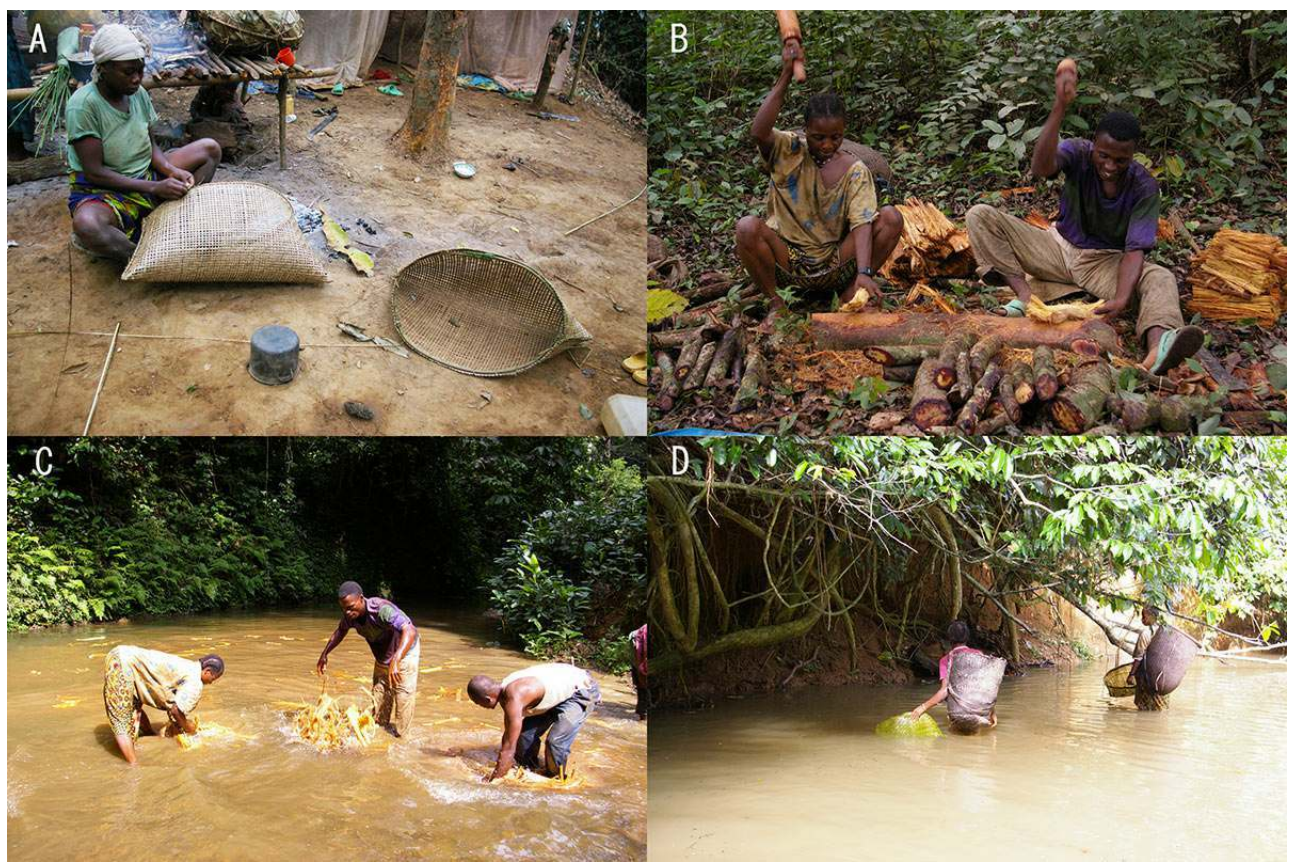

A: A Bakwele woman waving a MEKALA basket - B: Preparation of MONgonBo - C: Mixing MongonBo with mud - D: Harvesting fish with MEKALA

(c) T. OISHI 
sama (Turraeanthus africanus, Meliaceae) is a tall tree that grows inside the primary forest. asama is practiced in small streams even close to the village. The white thick bark of this species is used for poison fishing and is collected with machete (Figure 13). Participants weave baskets mekala from stems of Marantaceae plants to catch fishes. After that fish poison is put in the water, the expedition leader shouts "ngoma! ngoma!", urging the fish to come out. The other participants cannot enter the water before his signal. They wait calmly killing excitement. When the leader signs, everyone runs into the water and starts catching the fish.

Figure 13: Collecting ASAMA bark

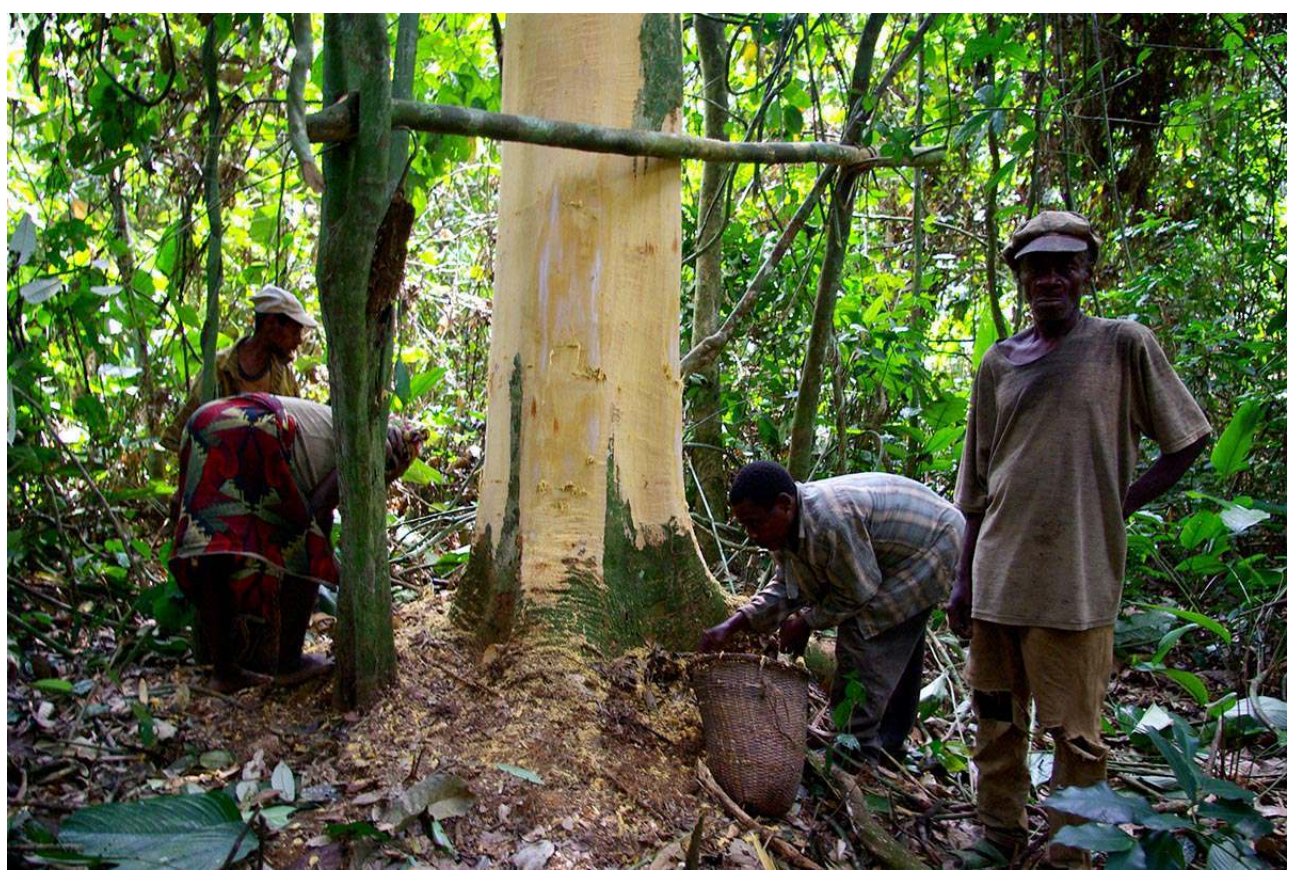

(c) T. OISHI

$3-$ Net

45 3-1. seli is small-scale gillnet of several meters long that is set perpendicularly to the river shore. In this fishing method cotton net is better than nylon net. The fisher sets net between two wooden sticks and checks it once to twice a day.

3-2, 3-3, 3-4. condo, londendi, and moteku are drift nets with variable mesh sizes (mesh of condo and moteku are 5 to 8 finger-sized; those of londendi are 2.5 to 3 finger-sized). Two dugout canoes are used to enclose the fishing ground. Conditions of riverbed are important: Drift netting is not applicable on places with rocky riverbed as nets may be caught at bottom and severely damaged.

\section{4 - Barrier}

47

When water receded in the end of the rainy season (November to December), a barrier $\boldsymbol{\varepsilon}$ léćb/ kala was constructed at the mouth of small streams. Setting a barrier was tributary of customary rights dating back to the time when the Bakwele's villages were 
established along the upper Dja river. After the resettlement of the Bakwele along the motor road, these rights fell into disuse and barrier fishing is no longer practiced today.

5 - Trap

5-1. tolo is a woven basket trap made of rattan liana and Raphia palm stems. It is sinked into the $\boldsymbol{\varepsilon}$-tok (deep place) in riverbed. Fish trapping with small sized tolo is less frequently practiced among the Bakwele compared to their Bangando neighbors.

5-2. laab $\mathbf{m} \boldsymbol{\varepsilon}$ ndii is a trap installed on the river shore. laab $\mathbf{m} \boldsymbol{\varepsilon} \mathbf{n d i m}$ is a specific type of trap targeting the large sized Clariid catfish ndim (Heterobranchus niloticus). A baited large size hook is tied to a wooden stick with a solid nylon wire that can bear intense weight. According to the Bakwele, ndim is a voracious fish that can eat "everything in the forest".

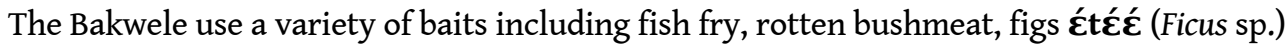
- ndim is said to particularly appreciate these fruits -, African bush mango fruits ( Irvingea gabonensis), African giant snail ngol (Achatina fulica), insects such as the African giant millipede gee (Archispirostreptus gigas), and even pieces of soap cut into small dice ( Figure 14).

Figure 14: Example of baits for LAAB ME NDIM

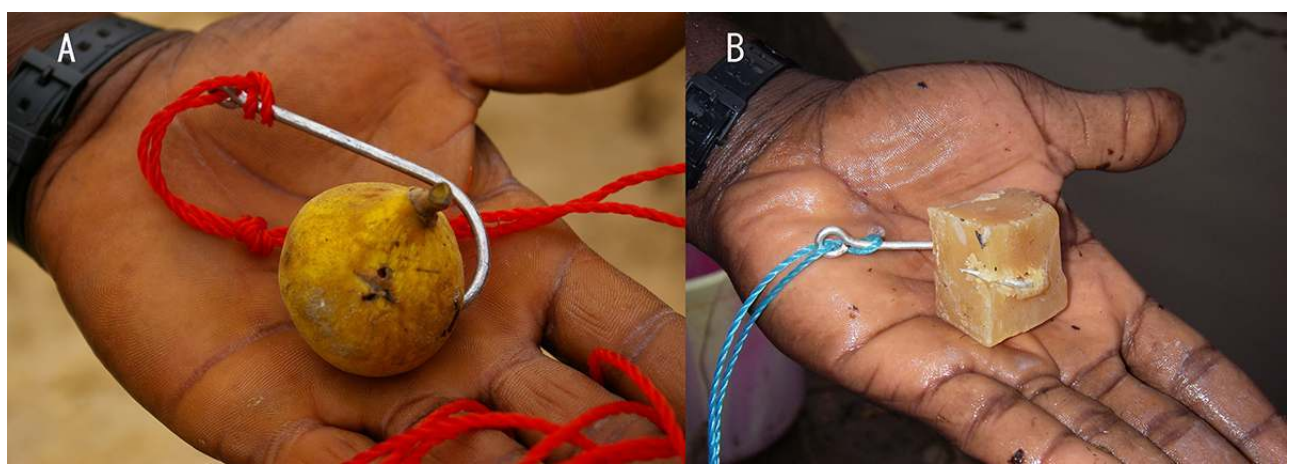

A: Whole fruit of $\dot{\varepsilon} \mathbf{T} \varepsilon \dot{\varepsilon}$ Ficus tree - B: SABUN soap

(C) T. OISHI

\section{6 - Hook and line}

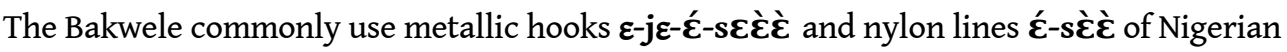
or Chinese origins, that are sold in the small retail shops of the village. Floats kombo of

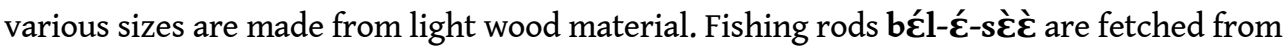
plant materials such as Raphia stems and other wood species. Artificial lures are nearly absent in the research area ${ }^{6}$.

6-1. à présent fishing consists to throw 1 or 2 hooks that are attached to a 20-50 meter long nylon line and ballasted with a sinker puulong. Earthworms are the most used baits. The nylon line is pooled with kombo-aprezáng. As suggested by the name à présent that means 'immediately' in local French, the fisher should not wait long before catching his first fish. In rocky riverbeds, freshwater oyster menaka are accused to cut the fishing line. 

bank and that gives its name to a fishing method. A reddish color cyprinid mboto is fond of mambelu fruits (Figure 15). The fisher baits his hook line with a mambelu fruit on hook and line and drop it onto the water from the shore. It is said that the catch will be easier if the fisher hits the water surface along with the bait. mboto is immediately attracted by the sound of the fruit hitting the surface.

Figure 15: MAMBELU fruits found in the stomach contents of a MBวTว fish

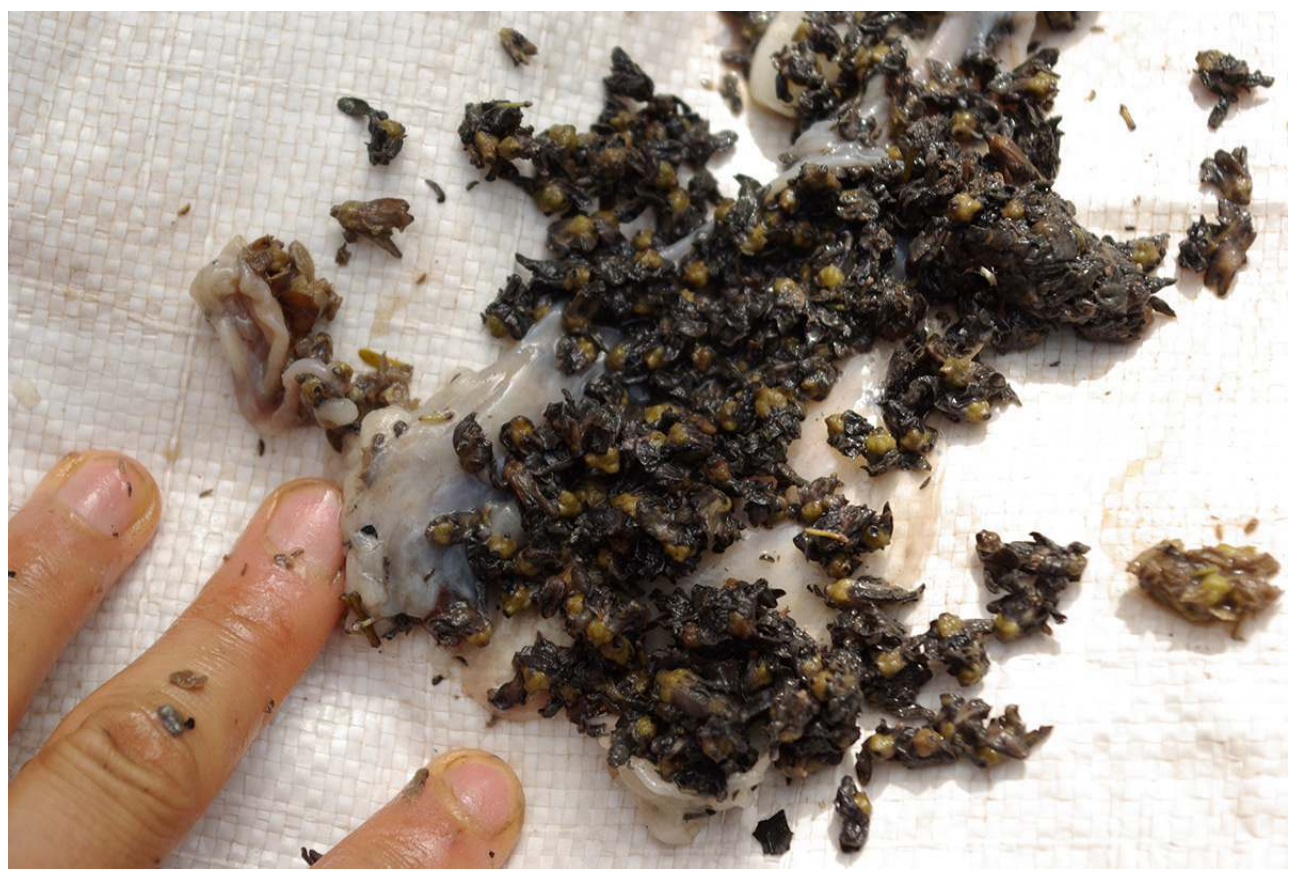

(C) T. OISHI

6-6. mattindi is a baited hook attached to the branch of a riverine tree with and nylon/ cotton wire. Big hooks (number one to three) are used to target large size fish. The wire length (about 2 meters long) is adjusted so that vertical position of hook will hang within 
a short distance under the water surface. After having installed his mattindi, the Bakwele fisher will spit out a small quantity of water stream to the surface (Esem-dii). It is believed that it will calm down the hooked fish. The fisher needs to visit mattindi every 2-3 hours as the caught fish may be opportunistically eaten by a crocodile (Figure 16).

Figure 16: Drawing by a Bakwele boy depicting a crocodile stealing a catfish from the hook of MATTINDI

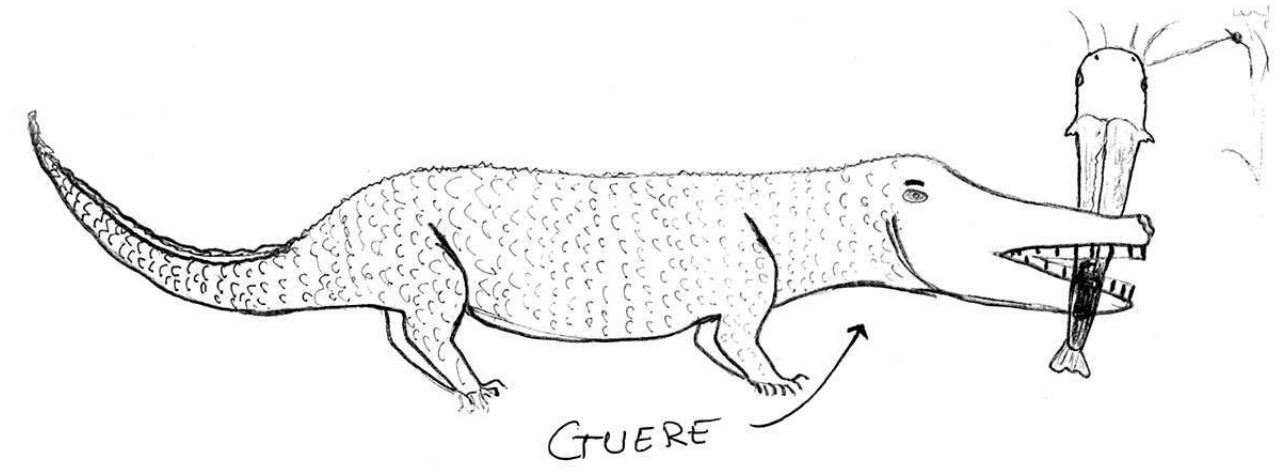

(C) T. OISHI

6-7. téléphone ${ }^{7}$ is a sort of mattindi with a live fish bait. The moves of the fish bait are aimed to attract the prey. The swinging wire that follows the bait move justifies the name given to this fishing method. Live baits are primarily captured by angling or other fishing methods and are kept alive inside a small cage dowala made of Raphia stems.

6-8. Egaka is a baited small-size hook (number six to eight) and cotton line attached to a small float made from stems of Raphia spp. Egaka fishing is practiced mostly by women and children in small streams and waterpools. Earthworms are used as baits. The float alerts when a fish is hooked.

\section{7 - Longline fishing}

7-1. boonp is a longline ( $50 \mathrm{~m}$ to $100 \mathrm{~m}$ long) composed of one or two hundreds small-size hooks (number four to six) baited with earthworms zappa. Longlines are installed before sunset to are visited in the next early morning.

7-2. kaba is a longline fishing method using small fish as baits. The fisherman sink dozens of large sized hooks (number one to three) connected to 10-30 meters of nylon cords ( Figure 17). This method targets large fish species such as kamba and ndim. When a large size fish is caught, pulling it out of the water can be risky for the fisherman who has to watch out not to be hooked by his own shaky hooks. Crocodiles sometimes come and eat the catches before that the fisherman is able to pull them out. Crocodiles may be hooked as well in some cases. 
Figure 17: A set of KABA with fresh baits of Alestids and Clarids

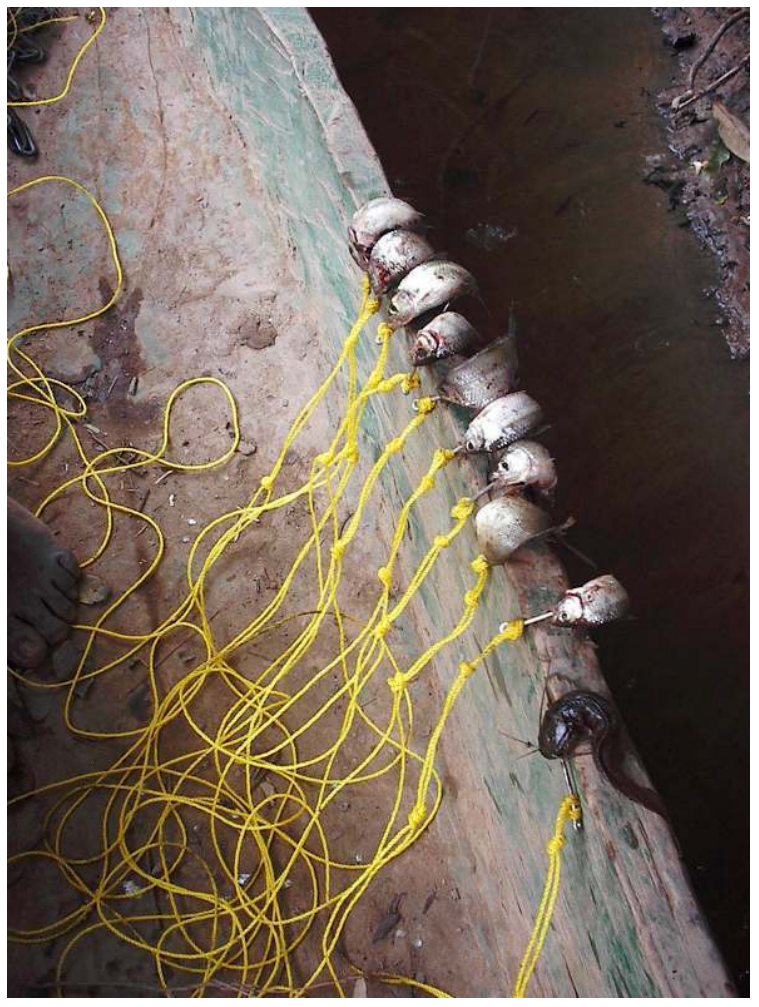

(c) T. OISHI

61 7-3. ngalu is a recently introduced longline fishing without baits. The fisherman sinks hundreds of large sized hooks (Number one to three) connected by short gangions to the lead nylon cords near the bottom of the Dja river. Immigrant fishermen who are said to have brought this type of longline in the area call it marie-marie. The few Bakwele fishermen who perform ngalu learned how to use it from immigrant fishers (Figure 18). 
Figure 18: An immigrant fisherman checking his NgALU installation in the Dja river

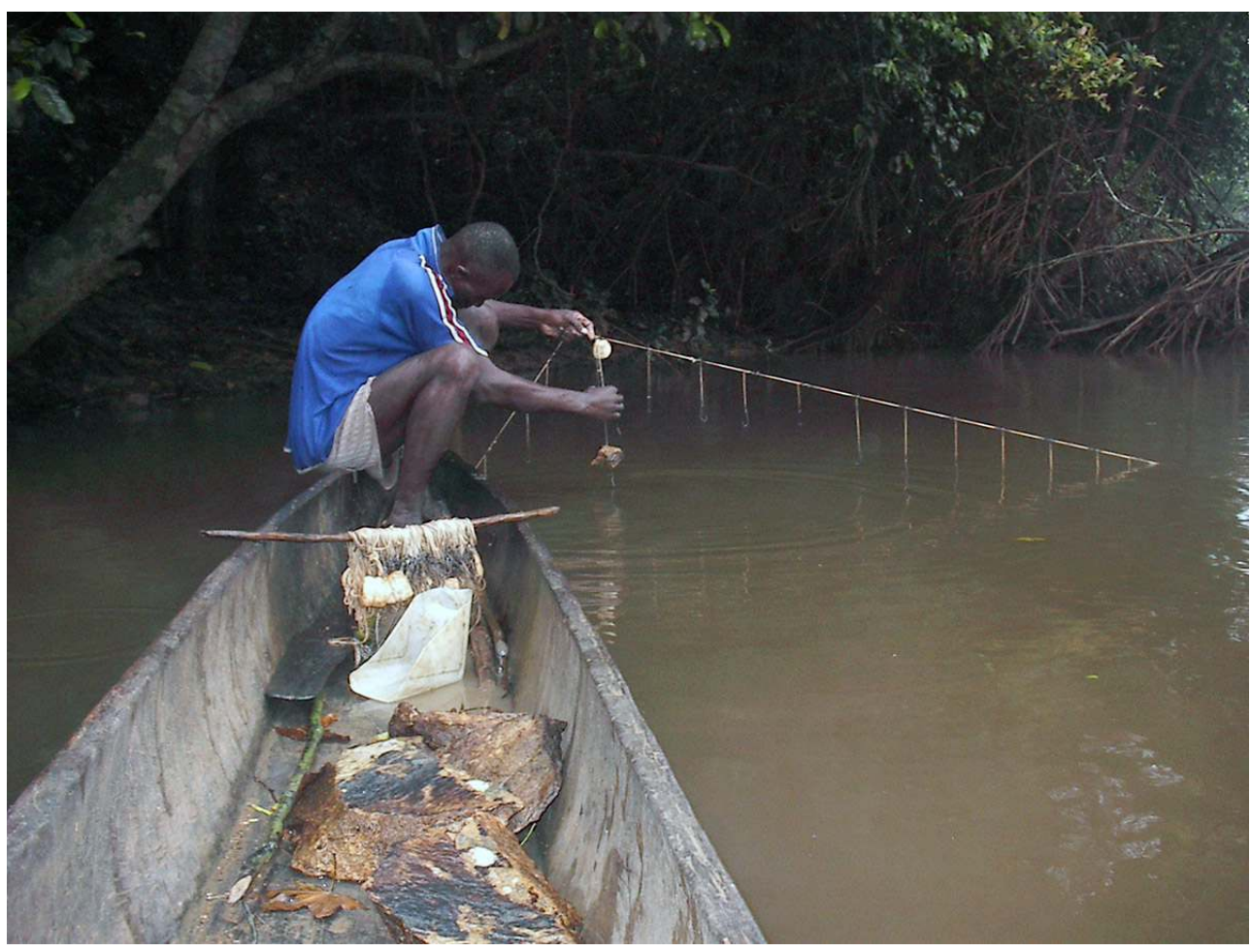

() T. OISHI

\section{8 - Harpoon}

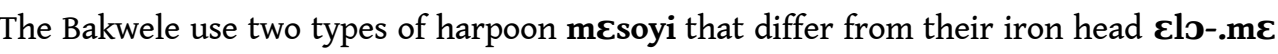
soyi. The iron head of bongo is detachable and has a single barb, while that of zdunga is fixed and counts two barbs.

8-1. mEsoyi, which literally means 'harpoon', is a rudimentary fishing method consisting of throwing the harpoon onto fish swimming by. Practiced individually or by 2-3 persons together, mEsoyi is mostly a recreational activity carried out by boys under a form of a competition: they start fishing at the same and in the same stream and will finally compare their catches when the decided time is over.

8-2. mEwupa is a kind of harpoon fishing that is performed during the major rainy season (October), individually or in pair or trio. After dusk, "when frogs start to cry loudly", the Bakwele fishermen go to forest with their harpoon (mesoyi) and flashlight for a halfnight or full night fishing. The Bakwele know how to recognize the migration trails of catfish that swim from the main Dja river up to booz sites in search for food and spawning spots. Once such trails are identified the fisher will stand by an expected passage point and will throw his harpoon when a fish passes by.

\section{9 - Collecting tutu}

65 It may happen that the Bakwele opportunistically collect dead fish or terrestrial mammals floating by on the water surface (Oishi 2010). They call them tutu and express no particular cultural avoidance regarding these dead catches. 


\section{Taboo and medicinal uses of fish}

From the interview of my key informants, 46 out of the 69 inventoried fish ethno-species were objects of taboos and restrictions. Under certain circumstances, these species are believed to bring sickness or disorder to some categories of people trying to eat or simply touch them. Seventeen out of 25 inventoried taboos address pregnant women and/or their mate and/or their newborn. Listed below are the freshwater fishes that may engender death or could be used as a counter-medicine among the Bakwele. When the fish morphology matters, the relevant part of fish body is illustrated by associated photographs.

\section{(A) Concerning a pregnant women and/or her mate and/or newborn:}

1. koto (Campylomormyrus sp., Mormyridae); Parents should not eat the head; Newborn's mouth would become long (Figure 19).

Figure 19: A sort of котЈ Campylomormyrus numenius

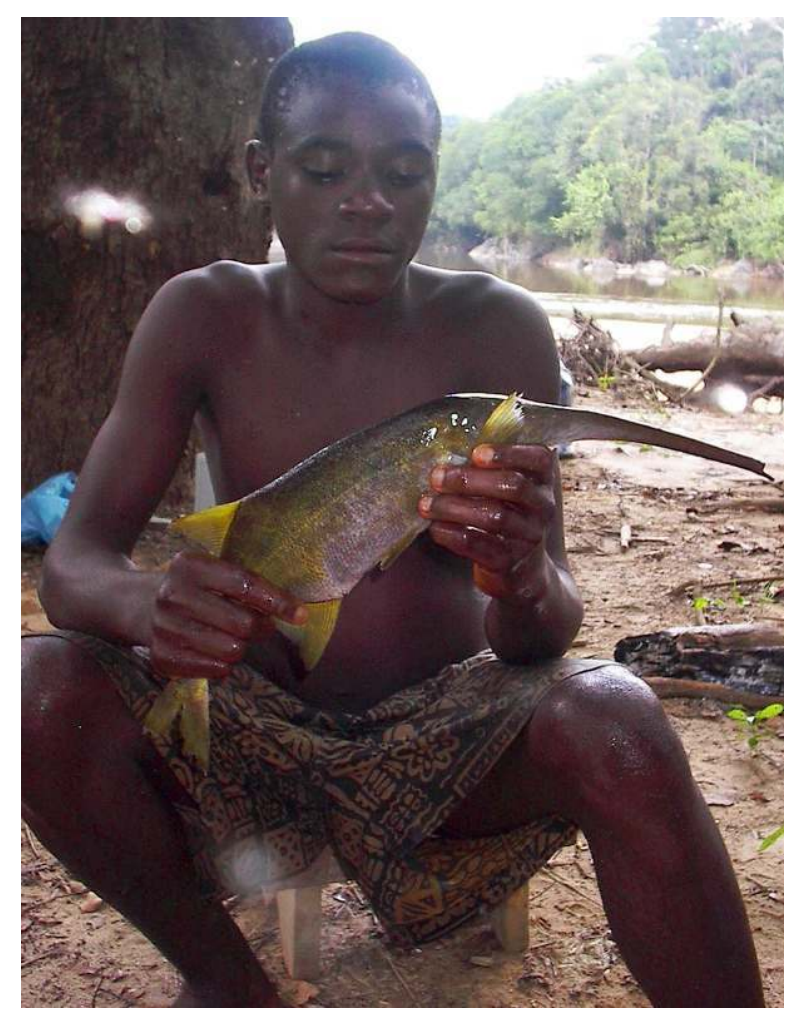

(C) T. OISHI

2. luem (Momyrus macrodon, Mormyridae); Parents should not eat any part; Newborn would not stop hiccough. (Figure 20). 
Figure 20: Juvenile of LUEM

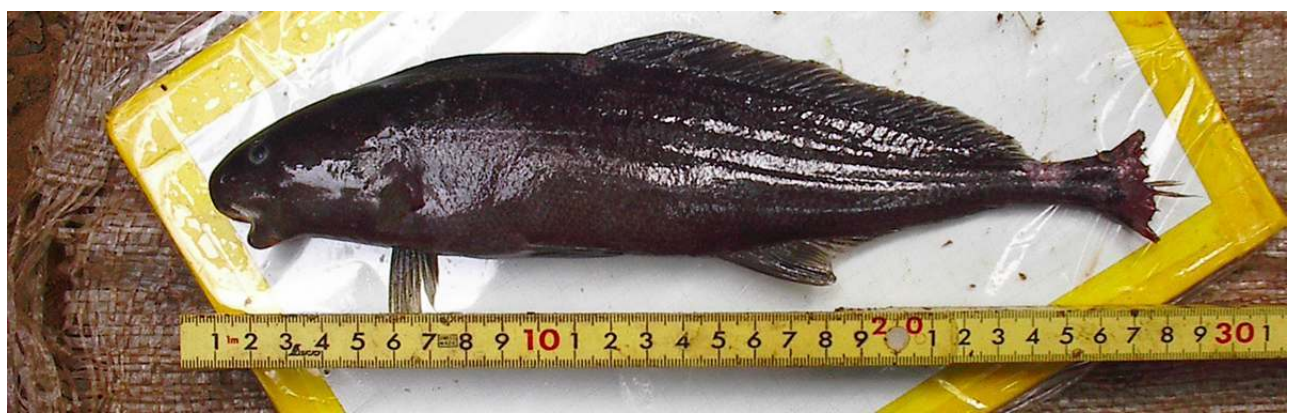

(C) T. OISHI

69 3. gعja (Auchenoglanis sp., Bagridae); Parents should not eat any part; Newborn's body would be blotched (Figur 21).

Figure 21: gعJA caught at fishing camp

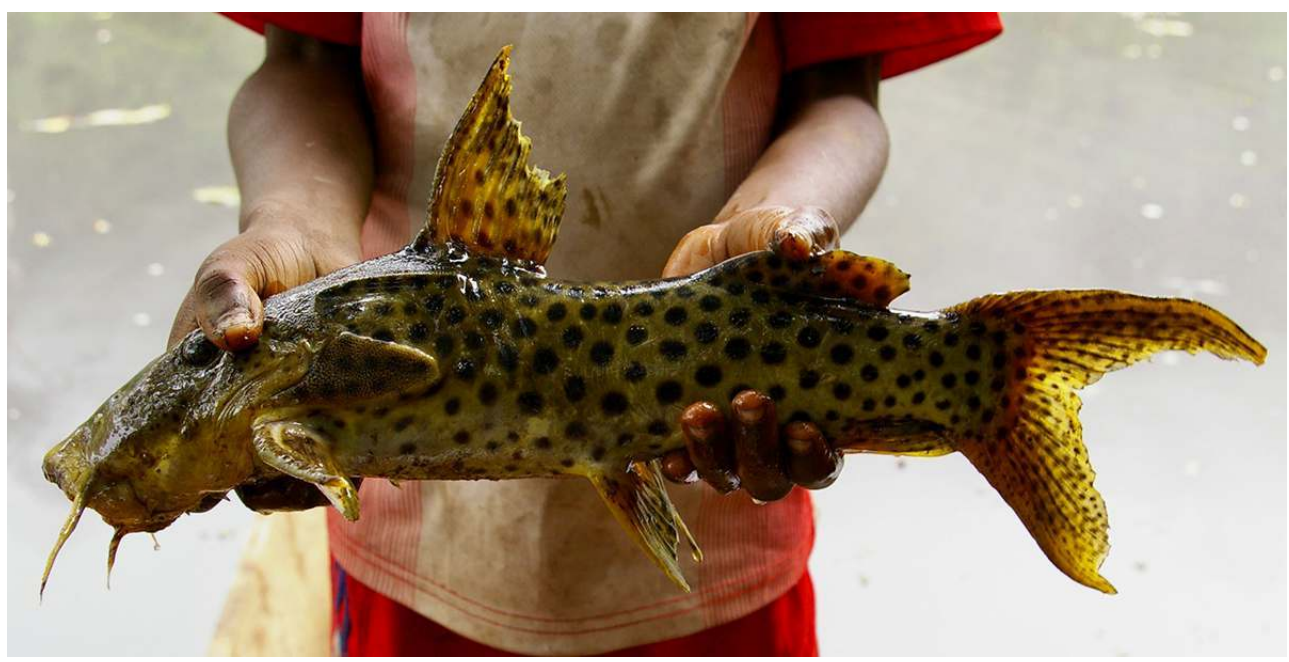

(C) T. OISHI

70 4. ka-kool (Xenomystus nigri, Notopteridae); Parents should not eat any part; Newborn would get cough, often also causes stomachache (Figure 22).

Figure 22: KA-KOOL (Xenomystus nigri) moves its fin as if it were a banana leaf

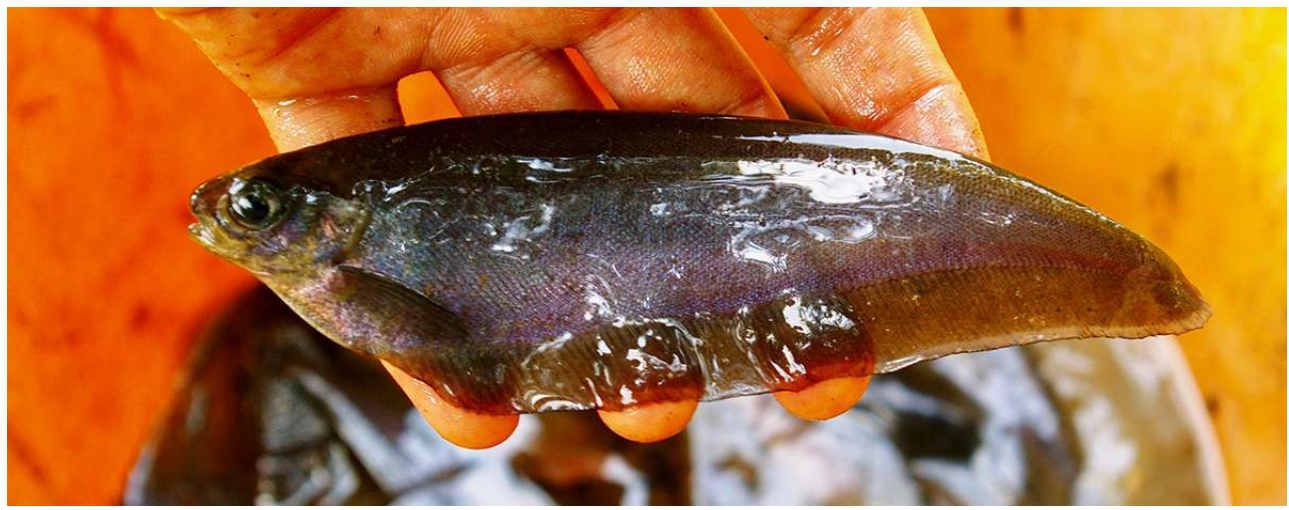

(C) T. OISHI 
71 5. gugu-boka (Tetraodon mbu, Tetraodontidae); If a pregnant woman steps on, delivery is announced very hard.

6. biyaal (Ichthyborus besse, Citharinidae) and biyaal mekuo (Ichthyborus quadrilineatus, Citharinidae) (Figure 23); Parents should not eat the head; Newborn would have bulging eyes.

Figure 23: biyaal mekuo captured with a BJכNP longline

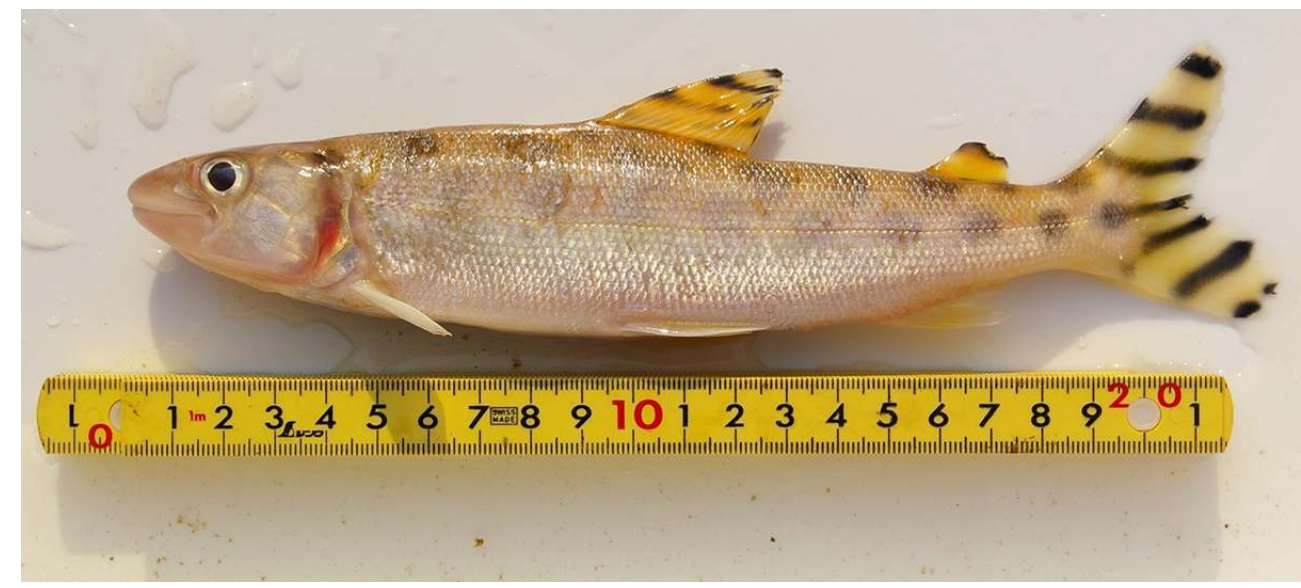

() T. OISHI

7. ngong (Calamoichthys calabaricus, Polypteridae); Parents should not eat any part; Newborn would have a long mouth and when it cries, it can not open the mouth properly. Women should not eat until nearing menopause.

8. pilu (Ctenopoma ocellatum and Ctenopoma oxyrhynchum, Anabantidae); Parents, other children, cousins should not eat any part; Newborn would not stop opening its mouth and emitting "choc, choc, choc..." or "kuroc, kuroc, kuroc..." sounds (Figure 24). 
Figure 24: Ctenopoma acutirostre caught by мعкÚк hook fishing

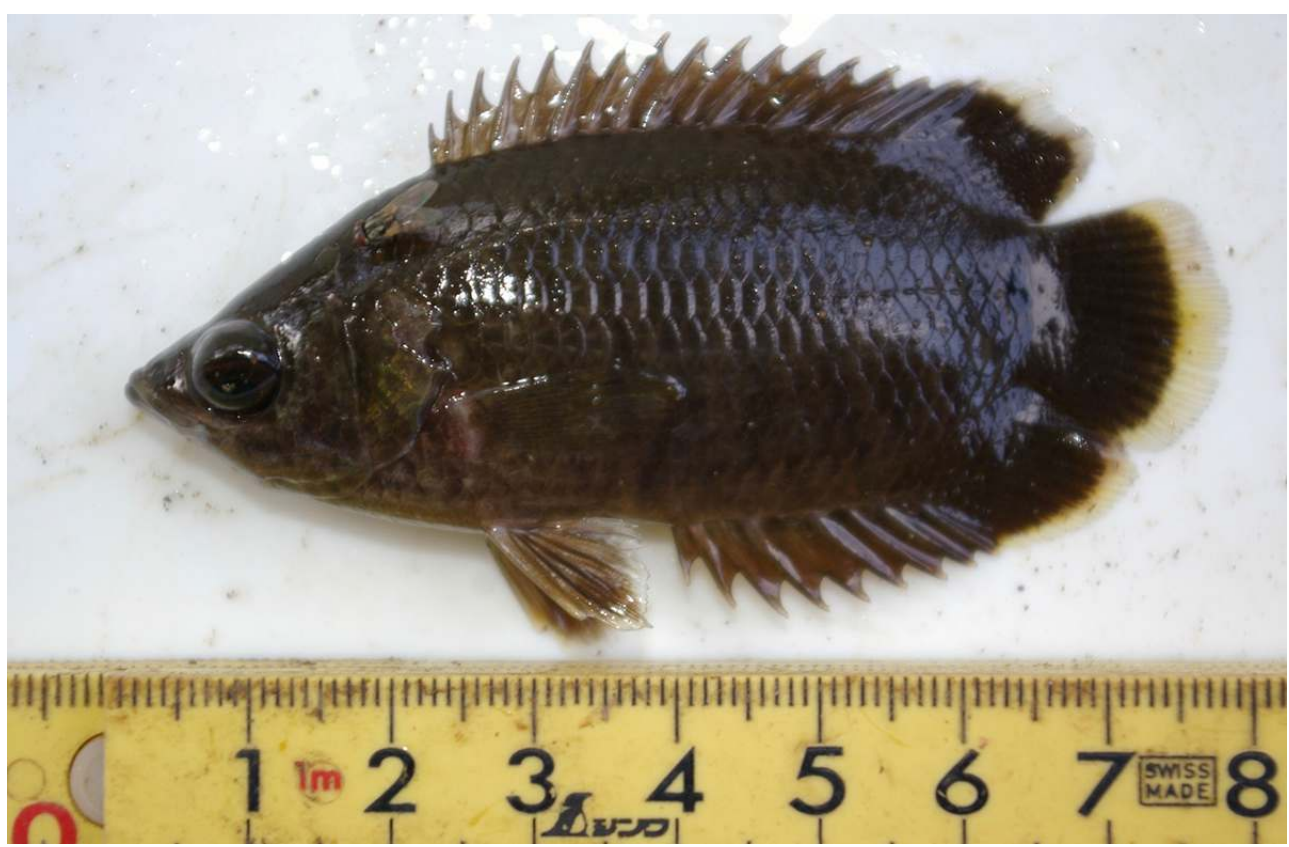

(c) T. OISHI

9. kJoga (Polypterus ornatipinnis, Polypteridae); Parents should not eat any part; Child's teeth would grow in all directions (Figure 25).

Figure 25: The teeth of $\mathbf{\text { KJJgA }}$

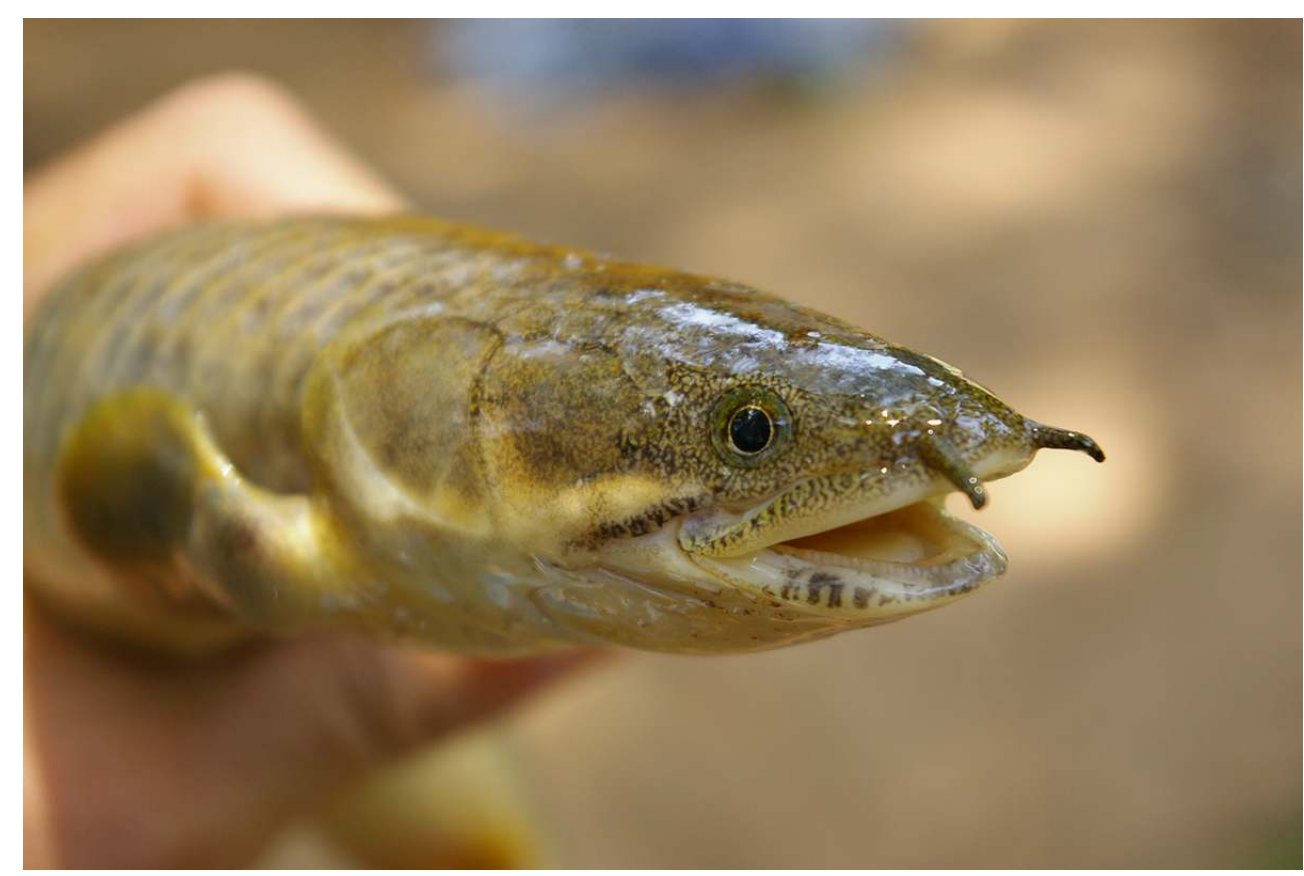

(C) T. OISHI

76 10. kongo-ya-shika (Heterotis niloticus, Arapaimidae); Parents should not eat any part; Newborn's mouth would be long. 

Newborn's ear would be doubled (Figure 26).

Figure 26: sù-PILAS swims and sometimes jump like a butterfly

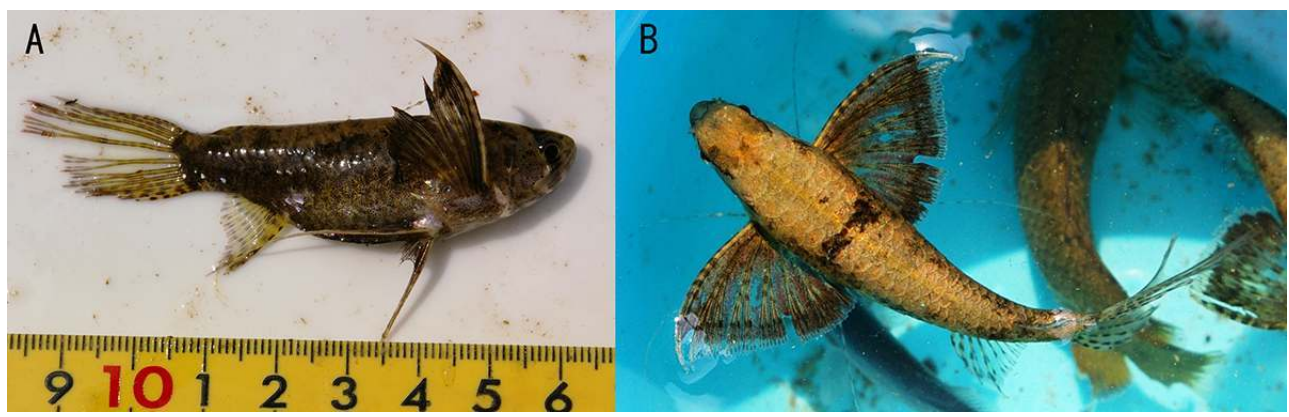

(C) T. OISHI

12. ndiya (Channallabes sp., Clariidae); Parents should not eat any part; Newborn would have a deformed face, with severe squared off jaws (Figure 27).

Figure 27: NDIYA is often caught by bailing fishing in an upstream waterpool

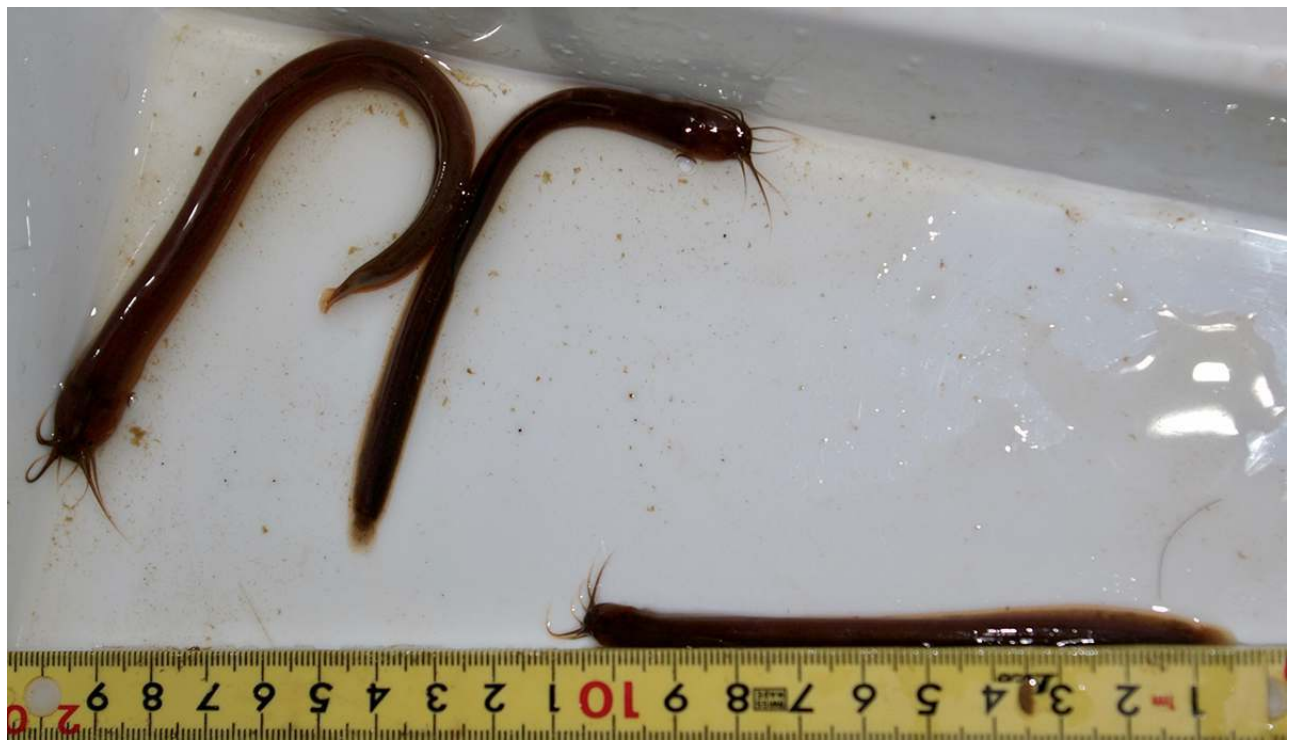

(C) T. OISHI

13. ndim (Heterobranchus longifilis, Clariidae), beme (Clarias sp., Clariidae) and kámbà ( Chrysichthys sp., Bagridae); The fish has a hole at the upper-head that evokes a baby's fontanel; Parents and small children should not eat any part; Disease called ndimel: The newborn would breath heavily, or his head would twitch as does the body of captured

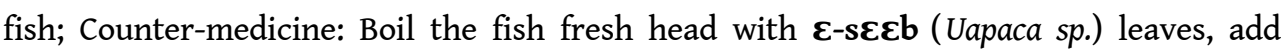
green pepper and parents give a spoon of this soup to their newborn (Figure 28). 
Figure 28: NDIM (Heterobranchus longifilis)

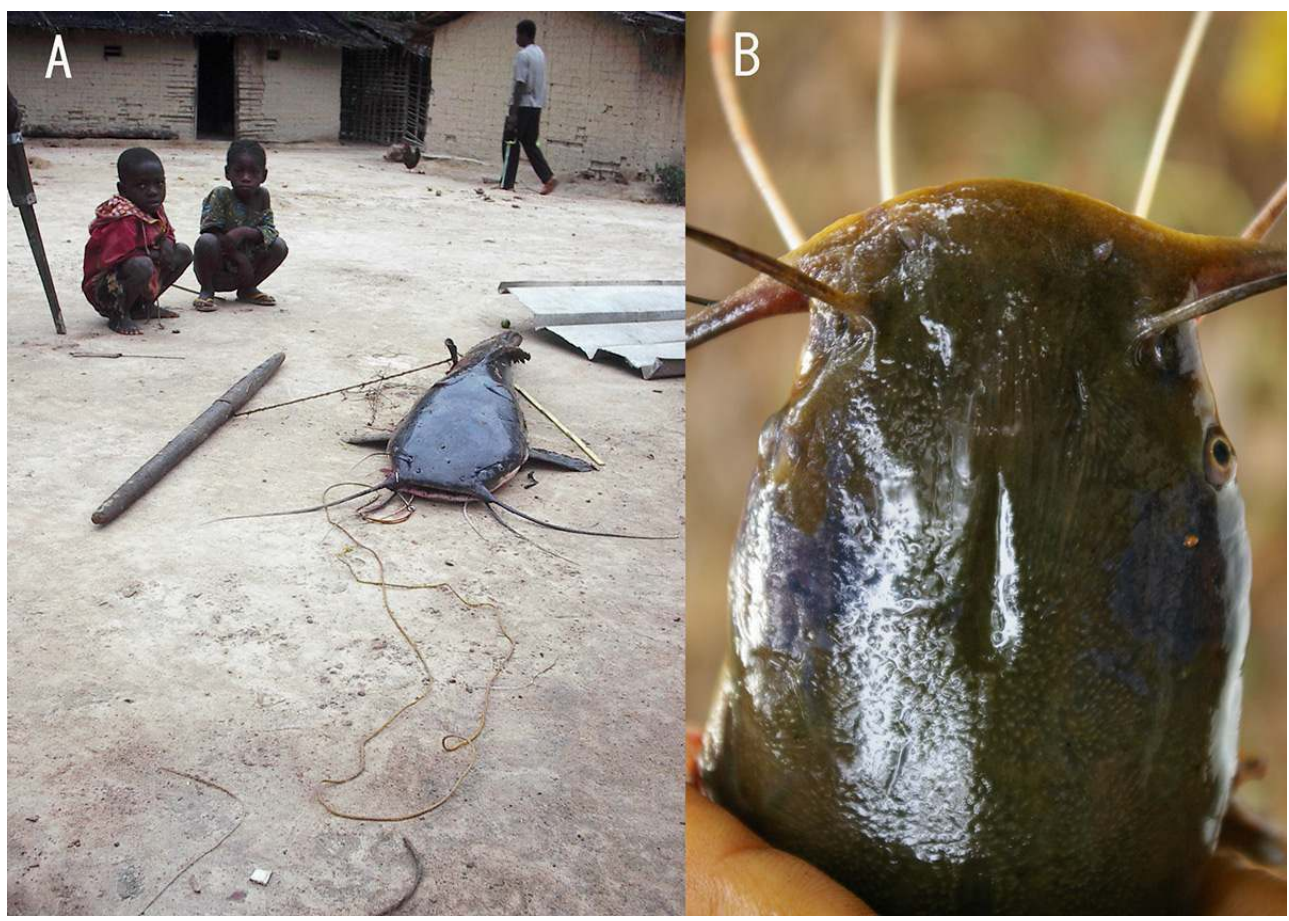

A: Large size adult - B: 'hole' at the upper head

(c) T. OISHI

14. edja (Petrocephalus catostoma; P. christyi; Marcusenius senegalensis, Mormyridae); Parents should not eat any part; Newborn would be breathless and would dead rapidly; The fish cries, "ng, ng, ng, ng..." (Figure 29).

\section{Figure 29: EDJA can not live long after its capture}

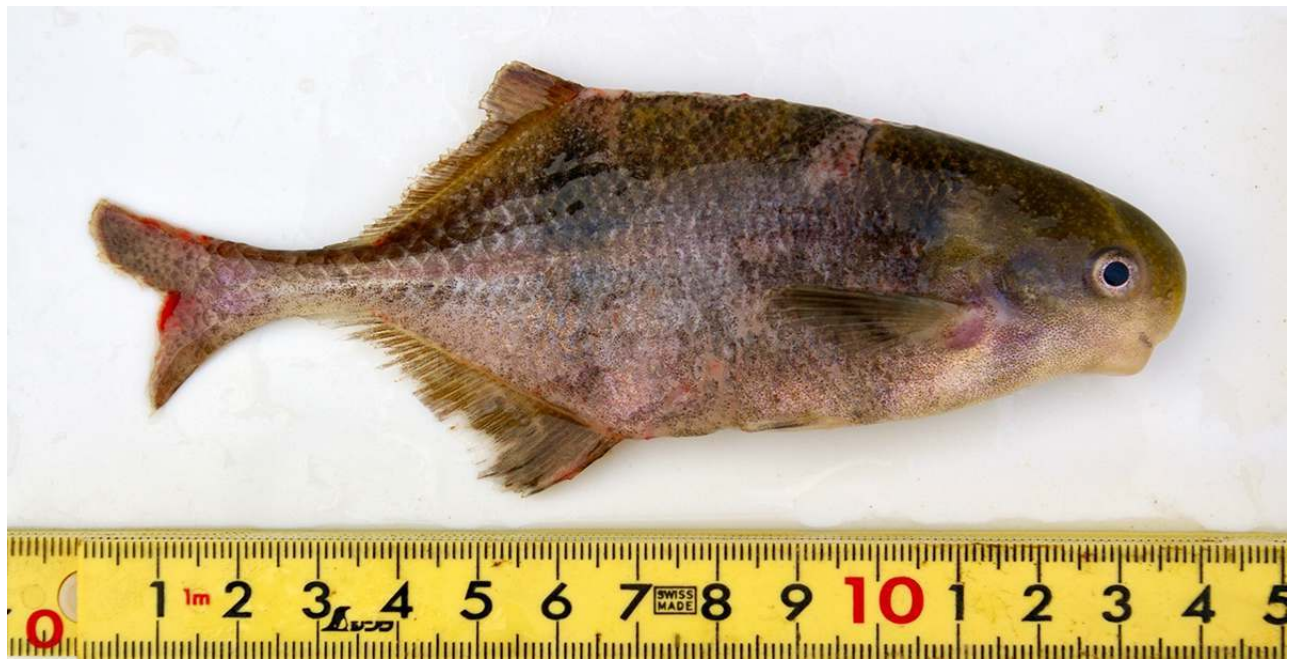

(C) T. OISHI

81 15. boka (Auchenoglanis occidentalis, Bagridae); Parents should neither kill nor eat it; Newborn would breath like a wild hog (Figure 30). 
Figure 30: ВЈKA is one of the most abundant catches from the main Dja river

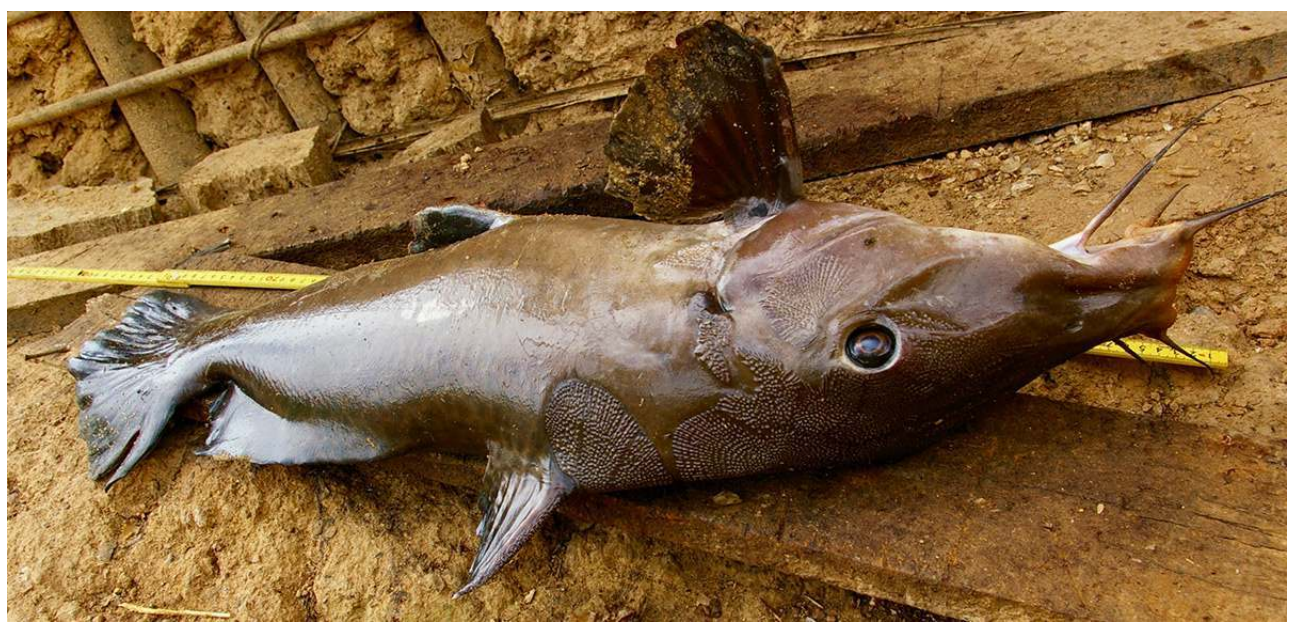

(C) T. OISHI

82 16. ningi (Synodontis acanthomias, Mochokidae); Parents should not eat any part; Newborn would cry like the fish, "kee, kee, kee..." (Figure 31).

Figure 31: The back of NINgI (Synodontis acanthomias) exhales a strong malevolent smell on its surface. It is recommended to remove it before cooking

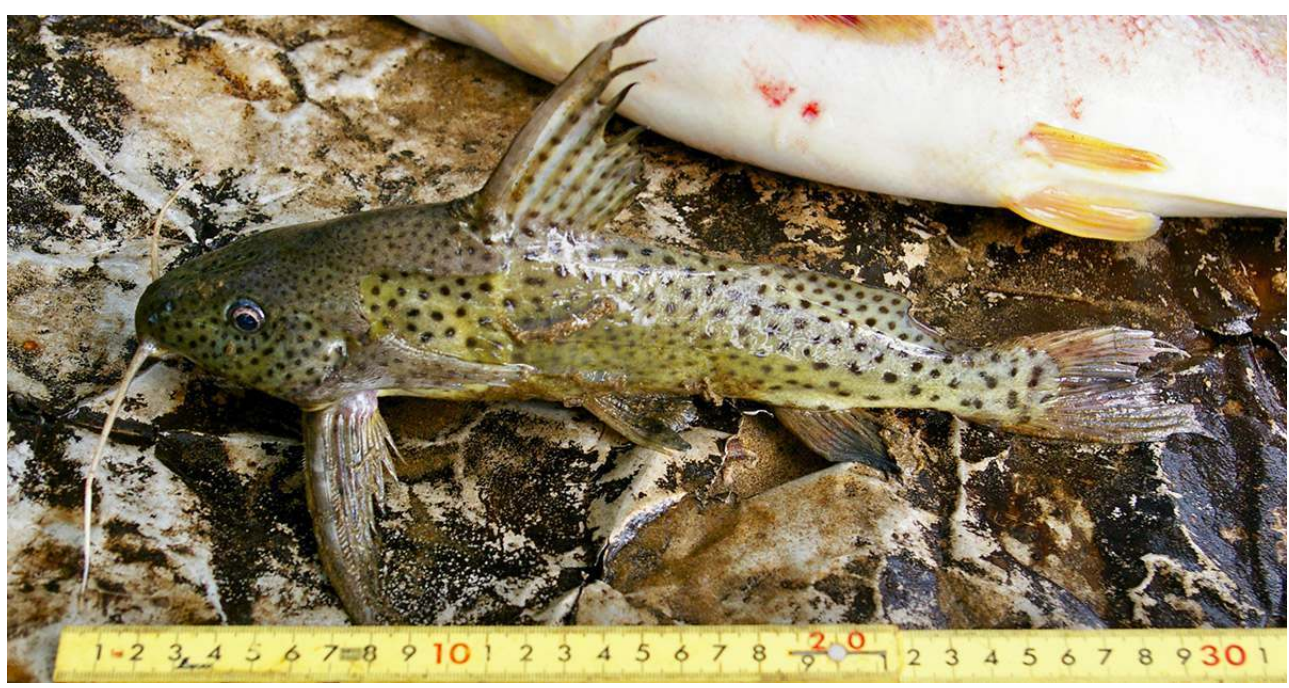

(C) T. OISHI

83 17. seya (Labeo lineatus; Cyprinidae), buok (Labeo cyclorhynchus; Cyprinidae), dabu (Labeo Greenii; Cyprinidae), nanumegwol (Labeo spp. including Labeo longipinis, Cyprinidae); Parents should not eat any part; Newborn would suffer from numerous eruptions around his mouth (Figure 32). 
Figure 32: Small outgrowths around the mouth of Labeo species evoke boils and other skin diseases

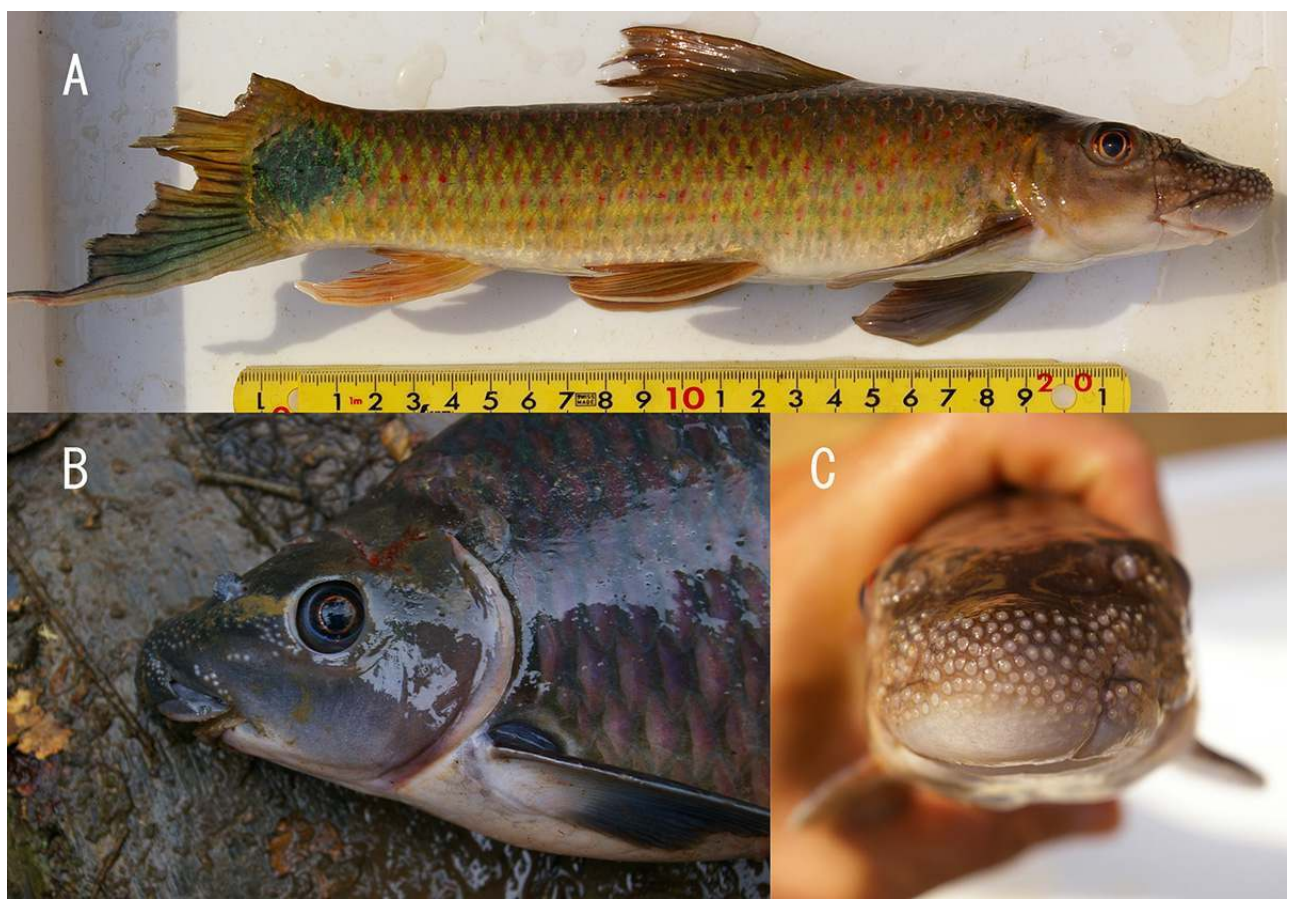

(C) T. OISHI

\section{(B) Concerning young women}

84 18. ngong (Calamoichthys calabaricus, Polypteridae); can delay menstruation.

(C) Medicine for a child

85 19. mengoko (Synodontis spp., Mochokidae); Can treat coughing and asthma (Figure 33). 
Figure 33: мعNgoко (Synodontis spp.) emits a crying sound when it si captured

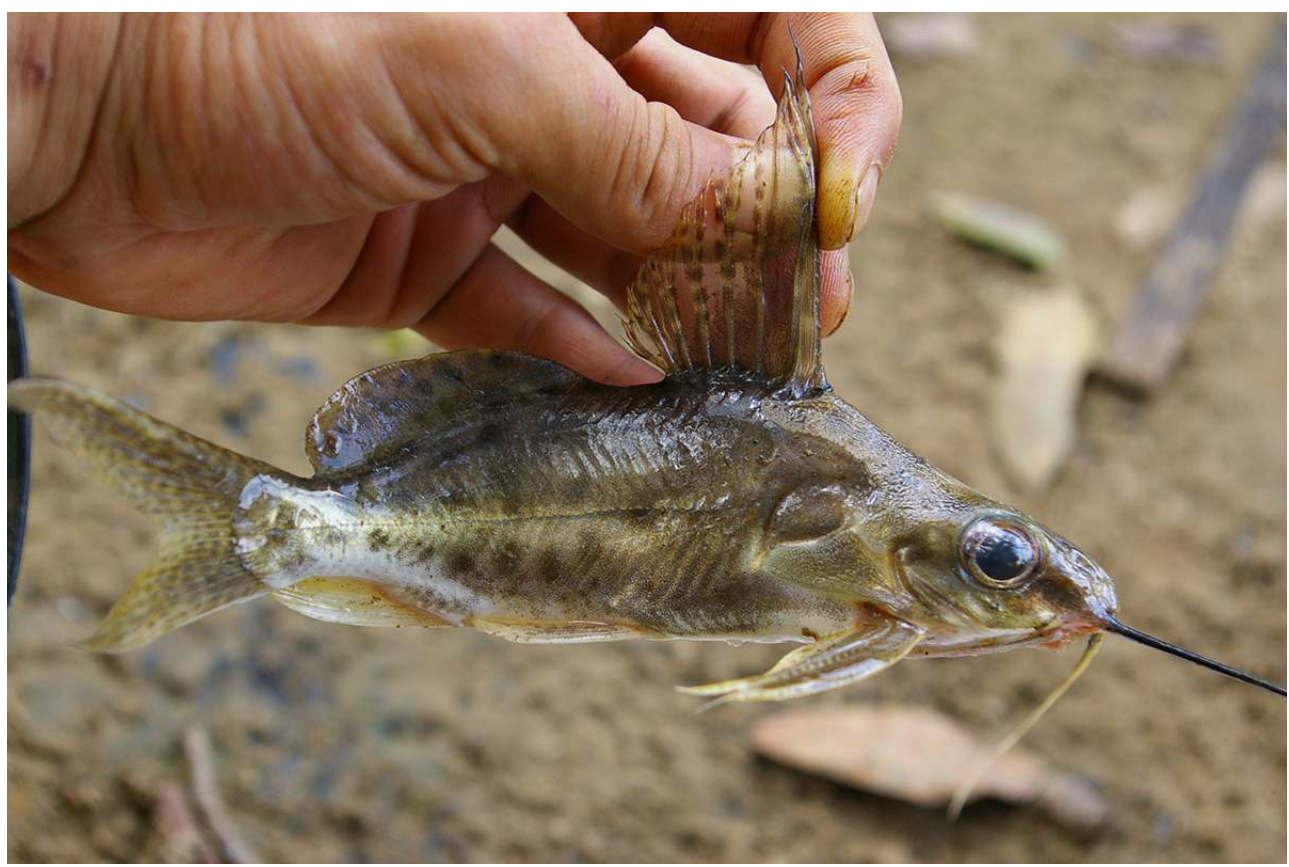

() T. OISHI

\section{(D) Medicine to become pregnant}

86 20. ngong (Calamoichthys calabaricus, Polypteridae); Used to rehearse pregnancy quickly after previous delivery.

21. gugu (Malapterurus electricus, Malapteruridae); Increases the development of the foetus and promises a strong and plump newborn to come (Figure 34).

Figure 34: gugu (Malapterurus electricus )

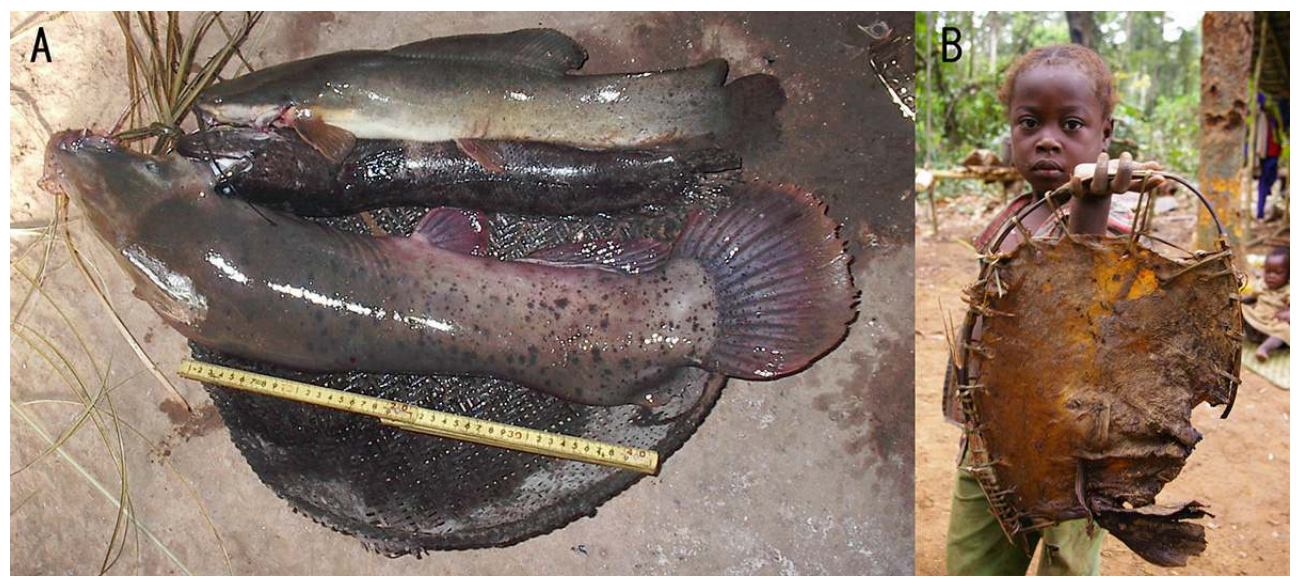

A: Freshly fished - B: Dried skin for medicinal use

(C) T. OISHI 


\section{(E) Medicine for men}

22. baaza (Phago sp.; Citharinidae); Used to treat impotence (Figure 35).

Figure 35: BAAZA (Phago sp.) has a very solid and elongated shape

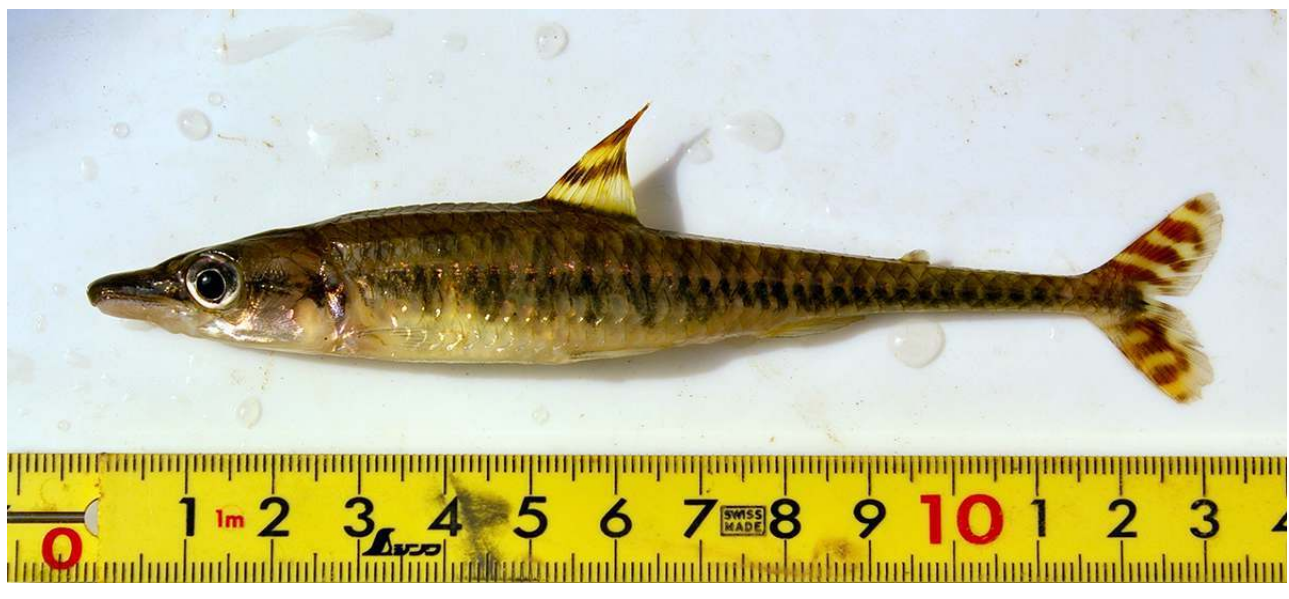

(c) T. OISHI

\section{(F) Medicine to fight}

89 23. gugu (Malapterurus electricus, Malapteruridae); Dry the nerve attached to the skin and grill it, then mix it with a medicinal plant (unidentified) and vaccine it on the back of hands with a knife to increase their punching power.

\section{(G) Medicine to all}

24. mEngoko (Synodontis sp., Mochokidae); Pectoral spines are used to remove any foreign matter that accidently entered the eye, like the very irritating seeds of the kapok tree (Ceiba pentandra, Bombacaceae) that are seasonally dispersed by wind.

\section{(H) Poison to kill others}

91 25. guguboka (Tetraodon mbu, Tetraodontidae); remove the quills from the raw skin of the fish and drop them into the watercourse in which the enemy and his family will take water or bathe (Figure 36). 


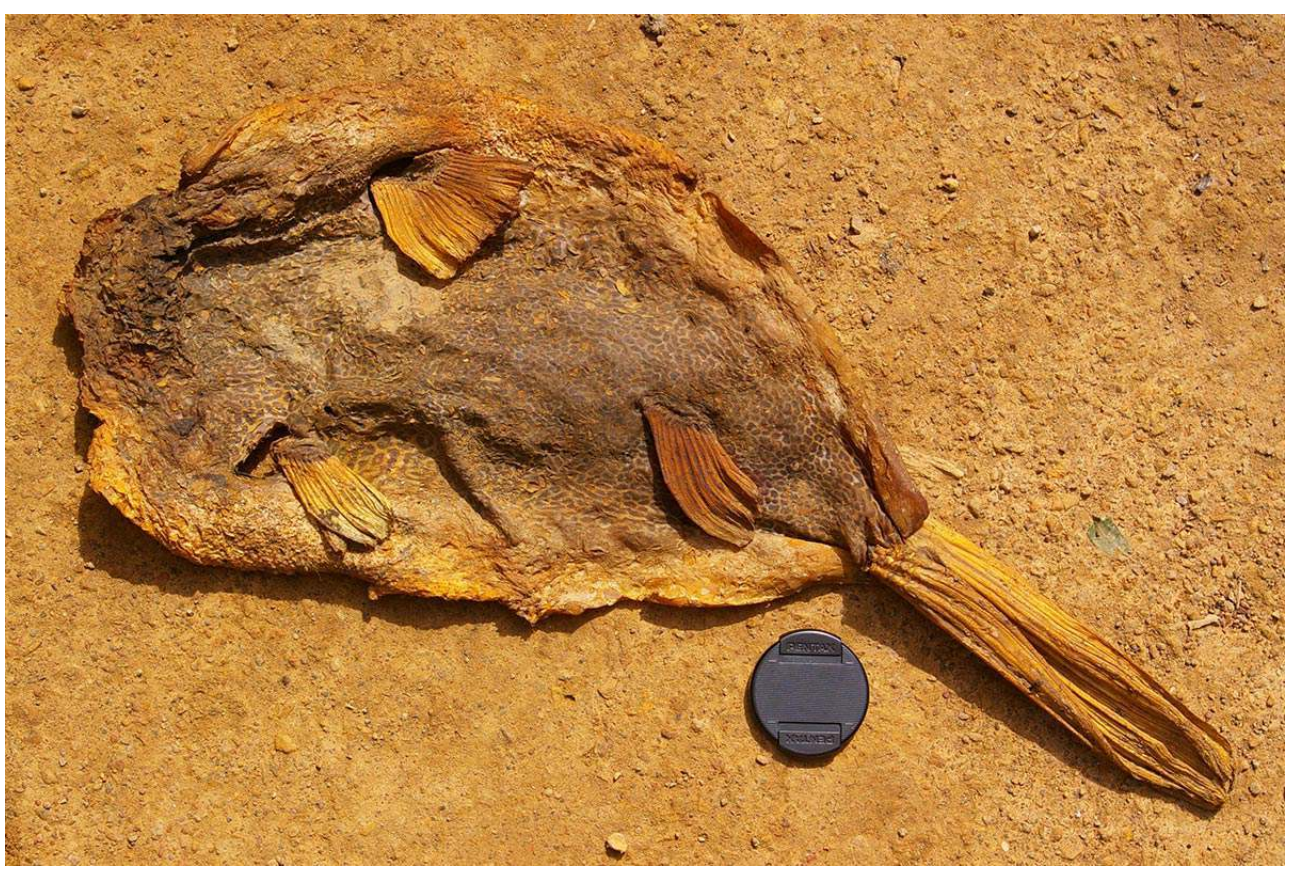

(C) T. OISHI

\section{Conclusion}

\section{Small-scale fishing targeting diverse fish species in rapidly changing environment}

The Bakwele have elaborated a great variety of fishing techniques that mediatize their extensive knowledge regarding fish ecology, diet, and behavior, in relation to diversified aquatic microhabitats. Most fishing methods are performed in very limited time and place. Each fishing practice requires a proper choice of fishing ground and an adjusted technique. For instance, fishing using hooks and lines (representing 8 out of the 26 inventoried fishing methods) necessitates to pinpoint fish habitat precisely. Bakwele's extensive fishing knowledge enables fishermen to adapt to their rapidly changing aquatic environment. In this regard, Bakwele fish ecology is practically rational.

Ankei (1989) and Paz \& Begoosi (1996) suggested that the economic environment tends to orientate the local folk taxonomies of fish, by grouping and ranking fish groups along with their economic value. I did not notice any influence of this type in the way Bakwele perceive and classify their fish maybe because the Bakwele capture fisheries are most exclusively designed for a domestic consumption. The limited propensity of the Bakwele to invest into costly fishing engines confirms their low commitment into commercial fishing. This distant attitude regarding market driven strategies resonates with the principle of minimum effort that still prevails in the livelihoods of many forest dwellers (Kakeya 1976). Furthermore, the Bakwele still attribute utmost importance to the taste of fish as food and to the value of fish in food taboos and medicinal uses.

\section{Integration of knowledge through embodiment of fish}


(1) behavior, and which is mobilized to adjust fishing practices, the Bakwele nourish their perceptual vision of the world with characteristics observed from fish. Aesthetic features and social values inspired from fish are essential to understand the overall Bakwele's cultural cognition on fish and inland waters. The Bakwele's daily and 'intimate' contacts with aquatic fauna have ultimately shaped their ethnomedicinal sphere of knowledge. High mortality among Bakwele newborns and young children is reflected by the fact that most of their diseases and taboos are related to reproduction (pregnancy, giving birth, early development during infanthood...). Following the classical doctrine of signatures, the Bakwele think that transgression of a food taboo targeting a fish with an abnormal feature will cause a disease to the child, with symptoms that will reproduce the deformity of the fish. The Bakwele always incorporate the diagnosed offending part of the fish in the remedy destined to cure this particular disease. Treatment against a fishoriginating disease also contains a counterpart plant harvested from the wild, and the sick newborn or child must receive the treatment from its parents. The ethnomedicinal knowledge on fish is embedded in broader relationships between the Bakwele and their natural environment. The Bakwele traditional healing system can also be seen as a symbolic means to bring together apparently antagonist components of the world - male versus female, plant versus animal - through the conciliation of which the therapeutic process can effectively operate.

97 Some commonalities among the taboos regarding fish species should be further addressed. Although preliminary, my results suggest that 1) morphologically 'strange' looking species 2) species that look like or behave like a sick, and 3) excessively tasty or nutritious species, are to be avoided. Bakwele's way to seek for the particular cause of a given sickness has a lot in common with that of the Baka Pygmies, as it was described by Sato (1998): Sato argues that Baka etyology is more naturalistic than personalistic in that the Baka consider sickness to be primarily caused by an exposure to natural forest pathogens. Diseases contracted by the Bakwele through the ingestion of or the direct contact with fish follow a similar interpretation and reveal the naturalistic side of their etyology. But fish are also strange mystical creatures that may transfer much less naturalistic abnormalities, as it is for instance reported among the Mbuti Pygmies (Ichikawa 1987). Accordingly, the personalistic side of Bakwele etyology should not be neglected: witchcraft is a common and popular practice throughout the Bantu populations of the Congo Basin, and the Bakwele are no exception. How both sides of thinking interact in the daily reality of the Bakwele certainly deserves further investigation.

The presented case study has strong limitations and weaknesses in sampling size and gender balance among informants. The small number of key informants cannot allow comparison of knowledge distribution according to age classes. Gender bias may surely exist in the results, especially with regard to the fundamental contribution of bailing fishing that is predominantly carried out by women and children. Further studies should definitely include more women as informants, and take a closer look at the differences in ethnoichthyological knowledge between generations. 
I am grateful to the Bakwele Djako of southeastern Cameroon who kindly welcomed me and authorized me to conduct research. The research was carried out under a research permission by the Ministry of Scientific Research and Social Innovation of Cameroon government. Prof. Akihisa Iwata of ASAFAS, Kyoto University gave me useful advices for the identification of fish specimens. This study was financially supported by Grant-in-Aid for Scientific Research (Nos. 13371006, 14401013, 2182001, 15H02601) from the Japan Society for the Promotion of Science, the Sasakawa Foundation for the Promotion of Science (No. 18-35), and the Sakura fund of the Society of Biosophia Studies.

\section{BIBLIOGRAPHY}

Akimichi T. 1978 - The ecological aspect of Lau (Somolon Islands) ethnoichthyplogy. The Journal of the Polynesian Society 87 (4) : 301-325.

Ankei Y. 1989 - Folk knowledge of fish among the Songola and the Bwari: Comparative ethnoichthyology of the Lualaba river and Lake Tanganyika fishermen. African study monographs Supplement Issue $9: 1-88$.

Bahuchet S. 1993 - La rencontre des agriculteurs: Les Pygmées parmi les peuples d'Afrique Centrale. SELAF, Paris.

Boulenger G.A. 1909-16 - Catalogue of the fresh-water fishes of Africa in the British Museum (Natural History). London, British Museum (Natural History), 4 volumes.

Brashares J.S., Arcese P., Sam M. K., Coppolillo P.B., Sinclair A.R. \& Balmford A. 2004 - Bushmeat hunting, wildlife declines, and fish supply in West Africa. Science 306 (5699) : 1180-1183.

Brummett R.E. \& Teugels G.G. 2004 - Rivers of the Lower Guinean rainforest: Biogeography and sustainable exploitation. Proceedings of the Second International Symposium on the Management of Large Rivers for Fisheries, Volume $2: 149-172$.

Brummett R., Nguenga D., Tiotsop F. \& Abina J-C. 2009 - The commercial fishery of the middle Nyong river, Cameroon: Productivity and environmental threats. Smithiana Bulletin 11 : 3-16.

Brummett R.E., Youaleu J. L.N., Tiani, A.M. \& Kenmegne M.M. 2010 - Women's traditional fishery and alternative aquatic resource livelihood strategies in the Southern Cameroonian Rainforest. Fisheries Management and Ecology 17 (3) : 221-230.

Chapman L.J. 2001 - Fishes of African rain forests. In Weber W., White L.J.T., Vedder A. \& Naughton-Treves L. (Ed.), African rain forest ecology and conservation: An interdisciplinary perspective. New Haven, Yale University Press : 263-290.

Cheucle M. 2008 - Vers une description de la langue bekwel (A85b) du Gabon: Approche synchronique, approche diachronique. Lyon, Master 2 report, Université Lumière Lyon 2, 214 p. Comptour M., Caillon S. \& McKey D. 2016 - Pond fishing in the Congolese cuvette: a story of fishermen, animals, and water spirits. Revue d'ethnoécologie 10. 
Dounias E., Cogels S., Mvé Mbida S \& Carrière S. 2016 - The safety net role of inland fishing in the subsistence strategy of multi-active forest dwellers in southern Cameroon. Revue d'ethnoécologie 10.

Gallois S. \& Duda R. 2016 - Beyond productivity: The socio-cultural role of fishing among the Baka of southeastern Cameroon. Revue d'ethnoécologie 10.

Gragson T.L. 1992 - Fishing the waters of Amazonia: Native subsistence economies in a tropical rain forest. American Anthropologist 94 (2) : 428-440.

Guthrie M. 1967-70 - Comparative bantu: an introduction to the comparative linguistics and prehistory of the Bantu languages. London, Gregg Press Ltd.

Hanawa R. 2004 - The dynamics of the relationship between shifting cultivators and huntergatherers along the Motaba of northern Congo (in Japanese with English abstract). Journal of African Studies $64: 19-42$.

Ichikawa M. 1987 - Food restrictions of the Mbuti Pygmies, eastern Zaire. African Study Monographs, Supplementary issue $6: 97-121$.

Inai H. 2010 - Co-existence of migrant fishers and local fishers: From the comparison of fishing practices in southeastern Cameroon (in Japanese). In Kimura D. \& Kitanishi K. (Ed.), People, nature and history of African tropical forests I: From ecological perspectives, Kyoto University Press, Kyoto : 373-397.

Joiris D.V. 1998 - La chasse, la chance, le chant: Aspects du systeme riturel des Baka du Cameroun. Bruxelles, Doctoral Thesis, Université Libre de Bruxelles.

Kakeya M. 1976 - Subsistence ecology of the Tongwe, Tanzania. Kyoto University African Studies 10 : 143-212.

Kimura D. 1992 - Daily activities and social association of the Bongando in central Zaire. African Study Monographs 13 (1) : 1-34.

Kimura D., Yasuoka H. \& Furuichi T. 2012 - Diachronic changes in protein acquisition among the Bongando in the Democratic Republic of the Congo. African Study Monographs, Supplementary Issue $43: 161-178$.

Lewis M.P., Simons G.F. \& Fennig C.D. (Ed.) 2016 - Ethnologue: Languages of the World, Nineteenth edition. Dallas, Texas: SIL International (http://www.ethnologue.com).

Makazi LC., Usongo L. \& Davenport T. 1998 - Indigenous aquatic resource use in the proposed protected area of Lobeke, south east Cameroon. Yaoundé, WWF-CPO Report.

Mengho M.B. 1978 - L'agriculture traditionnelle chez les Bakouélé et les Djem du Congo: Un exemple d'agriculture forestière. Les Cahiers d'Outre-Mer 31(121) : 48-84.

Oishi T. 2010 - Holidays in the forest: A case of fishing practice among Bakwele cultivators in southeastern Cameroonian rainforest. In Kimura D. \& K. Kitanishi K (Ed.), People, nature and history of African tropical forests I: From ecological perspectives, Kyoto University Press, Kyoto : 97-128.

Oishi T. 2012 - Cash crop cultivation and interethnic relations of the Baka hunter-gatherers in southeastern Cameroon. African Study Monographs Supplementary Issue 43 : 115-136.

Oishi T. 2014 - Sharing hunger and sharing food: Staple food procurement in long-term fishing expeditions of Bakwele horticulturalists in southeastern Cameroon. African Study Monographs, Supplementary Issue 47 : 59-72.

Oishi T. 2016 - Aspects of interactions between Baka hunter-gatherers and migrant merchants in southeastern Cameroon. Senri Ethnological Studies $94: 157-175$. 
Oishi T. \& Fongnzossie E. 2012 - Microhabitats in tropical mixed evergreen forest recognized by Baka hunter-gatherers of southeastern Cameroon: Folk concepts of vegetation change in comparison to modern ecological term of 'succession'. Paper presented at the 13th Congress of the International Society of Ethnobiology, May 21st, 2012, Montpellier, France.

Oishi T. \& Hagiwara M. 2015 - A preliminary report on the distribution of freshwater fish of the Congo river: Based on the observation of local markets in Brazzaville, Republic of the Congo. African Study Monographs, Supplementary Issue 51 : 93-105.

Paz V.A. \& Begossi A. 1996 - Ethnoichthyoplogy of Gaiviboa fishermen of Sepetiba bay, Brazil. Journal of Ethnobiology 16(2) : 157-168.

Poll M. \& Gosse J.P. 1995 - Genera des poissons d'eau douce de l'Afrique. Mémoire de la Classe des Sciences. Académie royale de Belgique 9 : 1-324.

Rowcliffe J.M., Milner-Gulland E.J. \& Cowlishaw G. 2005 - Do bushmeat consumers have other fish to fry? Trends in ecology \& evolution 20 (6) : 274-276.

Sato H. 1998 - Folk etiology among the Baka, a group of hunter-gatherers in the African rainforest. African Study Monographs, Supplementary Issue 25 : 33-46.

Sato H, Kawamura K., Inai H. \& Yamauchi T. 2006 - A "Pure" foraging lifestyle in a tropical rainforest of southeastern Cameroon: Observations on a twenty-day trip of the Baka huntergatherers in the short dry season (in Japanese). Journal of African Studies 69 : 1-14.

Siroto L. 1969 - Masks and social organization among the Bakwele people of Western Equatorial Africa. Ph. Dissertation, Columbia University.

Takeda J. 1990 - The dietary repertory of the Ngandu people of the tropical rain forest: an ecological and anthropological study of the subsistence activities and food procurement technology of a slash-and-burn agriculturist in the Zaire river basin. African Study Monographs, Supplementary issue $11: 1-75$.

Vansina J.M. 1990 - Paths in the rainforests: toward a history of political tradition in equatorial Africa. Madison, University of Wisconsin Press, 448 p.

Vivien J. 1991 - Faune du Cameroun. Guide des mammiferes et poissons. Imprimerie Saint-Paul, Mvolyé- Yaoundé.

\section{NOTES}

1. In this paper, vernacular terms are written using the International Phonetic Alphabet. High tones are marked with " ", low tones with " ". Synonyms or alternate expressions are preceded by a slash "/".

2. No reliable data are available concerning the Bakwele demography. This estimate is extrapolated from our own census in three local communities in Cameroon. The Summer Institute of Linguistics (https://www.ethnologue.com) reports 9,600 Bakwele in Republic of Congo and 2460 in Gabon.

3. Makazi et al. (1998) reported 62 spp. belonging to 19 families of fishes in Lobéké region adjacent to the research area.

4. Baka Pygmies call this hole as motonga. They dig the hole and exploit fish inside with spear and machete in their foraging expeditions (Sato et al. 2006).

5. Forest dweller's local perception and expression of the ambiguity of boundary between aquatic system and terrestrial system is amplified when evoking wetlands such as savanna floodplains. 
6. It is, however, practiced in Sangmelima area of southern region according to a personal communication of a Gbaya informant.

7. Until quite recently (early 2010s), telephone equipment had been seldom seen at the village.

\section{ABSTRACTS}

Ethnoichthyology is a branch of ethnobiology that explores the relationships between humans and fish, including local ecological knowledge about ichtyofauna, capture processes and utilization of the catches. Because of the current bushmeat trade crisis, the aquatic resources in the Congo Basin rainforest are increasingly viewed has promising alternate resources and have recently drawn the attention of conservation and development agencies. Yet, more attention should be given to the social context of fishing and to the cultural values locally attributed to fish. This paper describes some aspects of the ethnoichthyology of the Bakwele, a group of shifting cultivators of southeastern Cameroon. While focusing on the local ecological knowledge and the medicinal uses of fish by the Bakwele, the paper aims to emphasize the ecological and sociocultural interactions that form the basis of their art of fishing.

L'ethno-ichtyologie est une branche de l'ethnobiologie qui s'intéresse aux relations entre les humains et les poissons, ce qui inclut les savoirs naturalistes locaux sur les ressources aquatiques, les modalités d'acquisition et leur utilisation. Compte tenu de la crise actuelle du commerce de viande de brousse, les acteurs de la conservation et du développement s'intéressent de plus en plus aux ressources aquatiques du Bassin du Congo mais peinent à prendre la mesure du contexte social des activités traditionnelles de pêche et de la valeur culturelle que les peuples forestiers leur attribuent. Cet article vise à présenter certains aspects de l'ethno-ichtyologie des Bakwele, peuple d'agriculteurs sur brûlis du sud-est du Cameroun. L'accent est porté sur le savoir naturaliste et les usages médicinaux que les Bakwele font de l'ichtyofaune, afin de mieux rendre compte des interactions écologiques et socioculturelles qui constituent la base de leur art de la pêche.

\section{INDEX}

Population Bakwele (Cameroun)

Mots-clés: ethnoichtyologie, cognition culturelle, pêche artisanale en eau douce, techniques de pêche

Keywords: ethnoichthyology, cultural cognition, small-sale fishing, fishing techniques

\section{AUTHOR}

TAKANORI OISHI 